\title{
Generation and diversification of recombinant monoclonal antibodies for studying mitosis
}

Keith F. DeLuca ${ }^{1 *}$, Jeanne E. Mick ${ }^{1 *}$, Amy L. Hodges ${ }^{1}$, Wanessa C. Lima ${ }^{2}$, Lori Sherman ${ }^{3}$, Kristin L. Schaller ${ }^{4}$, Steven M. Anderson ${ }^{3,5}$, Ning Zhao ${ }^{1}$, Timothy J. Stasevich ${ }^{1,6}$, Dileep Varma ${ }^{7}$, Gary J. Gorbsky ${ }^{8}$, Jakob Nilsson ${ }^{9}$, and Jennifer G. DeLuca ${ }^{1 \#}$

${ }^{1}$ Department of Biochemistry and Molecular Biology, Colorado State University, Fort Collins, CO, USA

${ }^{2}$ Geneva Antibody Facility, Faculty of Medicine, University of Geneva, Geneva, Switzerland

${ }^{3} \mathrm{CU}$ Cancer Center Cell Technologies Shared Resource, University of Colorado Cancer Center, Anschutz Medical Campus, Aurora, $\mathrm{CO}$

${ }^{4}$ Department of Pediatric Hematology, Oncology and Bone Marrow Transplant, University of Colorado Anschutz Medical Campus, Aurora, $\mathrm{CO}$

${ }^{5}$ Department of Pathology, University of Colorado Anschutz Medical Campus, Aurora, CO, USA.

${ }^{6}$ Cell Biology Center and World Research Hub Initiative, Tokyo Institute of Technology, Yokohama, Japan

${ }^{7}$ Department of Cell and Developmental Biology, Feinberg School of Medicine, Northwestern University, Chicago, USA

${ }^{8}$ Cell Cycle and Cancer Biology Research Program, Oklahoma Medical Research Foundation, Oklahoma City, OK, USA

${ }^{9}$ The Novo Nordisk Foundation Center for Protein Research, University of Copenhagen, Faculty of Health and Medical Sciences, Copenhagen, Denmark

*Authors contributed equally

\#For correspondence: Jennifer G. DeLuca, jdeluca@colostate.edu

\section{Abstract}

Antibodies are indispensable tools used for a large number of applications in both foundational and translational bioscience research; however, there are drawbacks to using traditional antibodies generated in animals. These include a lack of standardization leading to problems with reproducibility, high costs of antibodies purchased from commercial sources, and ethical concerns regarding the large number of animals used to generate antibodies. To address these issues, we have developed practical methodologies and tools for generating low-cost, high-yield preparations of recombinant monoclonal antibodies and antibody fragments directed to protein epitopes from primary sequences. We describe these methods here, as well as approaches to diversify monoclonal antibodies, including customization of antibody species specificity, generation of genetically encoded small antibody fragments, and conversion of single chain antibody fragments (e.g. scFv) into full-length, bivalent antibodies. This study focuses on antibodies directed to epitopes important for mitotic cell division; however, the methods and reagents described here are applicable to antibodies and antibody fragments for use in any field. 
41

42

\section{Introduction}

Antibodies are used in a diverse array of applications in the biomedical sciences including detection of biomolecules in cells, tissues, and biological fluids; protein purification; functional depletion of proteins from cells and cell extracts; medical diagnostics, and therapeutic medicine. While these reagents are essential for almost all areas of research in the biosciences, there are drawbacks to using traditional antibodies generated in animals. First, there are growing concerns regarding reproducibility, and this is in part due to a lack of standardized and thoroughly defined immunological reagents. In many cases, antibodies are incompletely characterized, not well understood at the molecular level, and variable in performance across lots (Bradbury and Plückthun, 2015; Bordeaux et al., 2010; Bradbury et al., 2018; Baker, 2015; Weller, 2016). Second, the continued availability of traditionally generated antibodies is not guaranteed, as the existence of such reagents depends on active maintenance and storage, or continued production in animals (Cosson and Hartley, 2016). Third, traditional, commercially available antibodies are expensive. For many researchers these costs are prohibitive and in turn, significantly limit productivity and research innovation. Finally, a large number of vertebrate animals are used for the generation of traditional antibodies for biomedical research, which presents ethical concerns (Gray et al., 2020; Gray et al., 2016; Leenaars et al., 1998).

In recent years, it has been possible to sequence monoclonal antibodies from purified antibody samples and from hybridoma cell lines such that their primary amino acid composition is explicitly identified (Lima et al., 2020; Cosson and Hartley, 2016; Vazquez-Lombardi et al., 2016). In addition, techniques have been developed in which antibodies to nearly any antigen can be isolated through clonal selection of sequence-defined antibody fragments (Gavilondo and Larrick, 2000; Saeed et al., 2017; Alfaleh et al., 2020; Almargo et al., 2019; Laustsen et al., 2021). Using these approaches, the generation of sequencedefined recombinant antibodies and antibody fragments is feasible, which circumvents many of the problems listed above regarding traditionally generated antibodies. First, using recombinant antibodies generated from an invariant primary sequence increases reagent reproducibility. Second, after a primary sequence is determined, recombinant antibodies and their derivatives are accessible in perpetuity. Third, recombinant antibodies can be produced in large quantities using low-cost expression and purification systems, such that researchers can produce large-scale yields of recombinant antibodies for a fraction of the cost of antibodies purchased from commercial sources. In addition, plasmids are easily distributed for direct expression in cell line of choice. Finally, the use of recombinant antibodies significantly reduces the number of animals required for antibody production.

An additional advantage of recombinant antibodies is the potential for increased reagent versatility. With the primary amino acid sequence of an antibody in-hand, researchers can diversify the original reagent and create derivative tools such as antibody fragments, that can be genetically fused to other protein 
molecules, such as fluorophores, to generate custom tools with diverse functionalities. Here we describe methods and tools for generating low-cost, high-yield preparations of recombinant monoclonal antibodies and antibody fragments from mammalian cell culture, benchmarking the approach with mitotic epitopes.

80 Furthermore, we describe straightforward and accessible approaches to diversify immunological 81 reagents including customization of antibody species specificity, generation of genetically encoded small 82 antibody fragments, and conversion of single chain antibody fragments (e.g. scFv) into full-length, 83 bivalent antibodies. While this study focuses on antibodies relevant to cell division and mitosis, these approaches are widely applicable for antibodies and antibody fragments across fields.

\section{Results}

\section{Generation of recombinant monoclonal antibodies to mitotic targets}

In the process of mitosis, chromosomes must properly segregate into two daughter cells in order to maintain genomic integrity. Kinetochores are structures built at the primary constriction of mitotic chromosomes which mediate attachments to spindle microtubules and are largely responsible for both powering and regulating chromosome congression and segregation (Musacchio and Desai, 2017). The primary factor that connects kinetochores to microtubules is the kinetochore associated NDC80 complex, and within this complex the Ndc80/Hec1 subunit serves as the direct link to microtubules (DeLuca and Musacchio, 2011; Varma and Salmon, 2013; Wimbish and DeLuca, 2020). Research in many labs utilizes the Hec1 monoclonal antibody "9G3", which was originally generated in mice to a purified protein fragment encompassing amino acids 56-632 of the human Hec1 protein (Chen et al., 1997). The specific epitope was later mapped using peptide array analysis to amino acids 200-215, a region which resides within the well-ordered calponin homology domain of the protein (DeLuca et al., 2006). While this antibody is commercially available, the quality of the antibody is variable between lots, which is not uncommon in the case of commercially produced immunological reagents (Pozner-Moulis, 2007; Garg and Loring, 2017; Katzman et al., 2017; Bradbury and Plückthun, 2015; Bordeaux et al., 2010; Bradbury et al., 2018; Baker, 2015; Weller, 2016).

To ensure its continued consistency, we sequenced the 9G3 Hec1 mouse monoclonal antibody (Rapid Novor, Kitchener, Ontario, Canada) using tandem mass spectrometry with W-ion isoleucine and leucine determination (Johnson et al., 1987; Zhokhov et al., 2017). A $100 \mu \mathrm{g}$ sample of purified monoclonal antibody was used as the source material for sequencing. Figure $1 \mathrm{~A}$ shows the antibody sequence and annotations for the hyper-variable regions (HVR, also known as complementarity determining regions or CDRs) in green, the framework regions (FR) within the variable regions in blue, as well as the constant regions (CR1, CR2, and CR3 in the heavy chain; CR in the light chain) in orange. The heavy chain was identified as class lgG2a and the light chain as kappa (Figure 1A, B). We next generated geneblocks encoding for both heavy chain and light chain sequences optimized for expression in human cells. The 

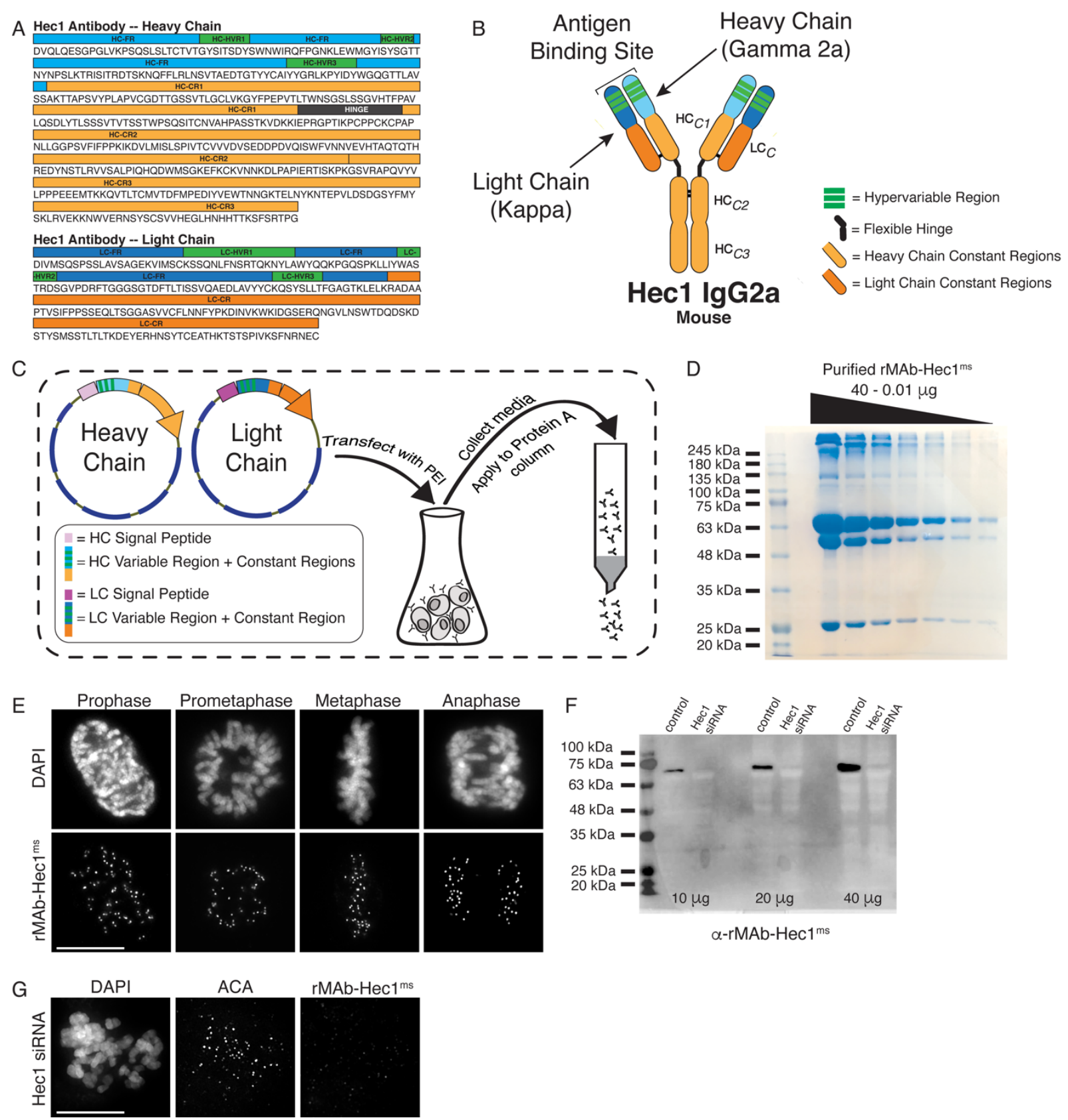

ACA
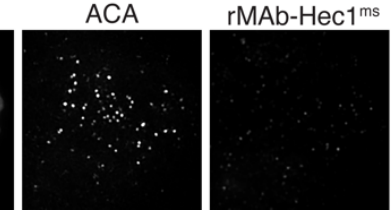

Figure 1. Generation of a recombinant Hec1 monoclonal antibody. (A) Sequence data obtained for the Hec1 monoclonal antibody is annotated for the heavy chain $(\mathrm{HC})$ and light chain $(\mathrm{LC})$ variable regions ( $\mathrm{HC}=$ light blue; $\mathrm{LC}=$ dark blue), hypervariable regions (green), constant regions ( $\mathrm{HC}=$ light orange; $\mathrm{LC}=$ dark orange), and the flexible hinge (dark gray). (B) rMAb-Hec $1^{\mathrm{ms}}$ antibody structure and nomenclature. (C) Cloning, transfection, and purification scheme. Heavy and light chain coding regions were cloned into separate plasmids for transfection into human Expi293F cells. Cell media containing secreted antibodies was collected and applied to a Protein A Sepharose column. After column washing, antibodies were eluted using a low pH buffer. (D) Purified rMAb-Hec $1^{\mathrm{ms}}$ antibody was serially diluted and run on a $12 \%$ SDS- polyacrylamide gel. The prominent band that runs above the $245 \mathrm{kDa}$ molecular mass marker is likely a population of non-denatured antibody. The bands running at $\sim 63 \mathrm{kDa}$ and $\sim 50 \mathrm{kDa}$ are glycosylated and non-glycosylated heavy chains, respectively. The antibody light chain runs at $\sim 25 \mathrm{kDa}$. (E) HeLa cells immunostained with the purified rMAb-Hec1 ${ }^{\mathrm{ms}}$ antibody. Cells were also stained with DAPI to detect chromosomes. (F) Immunoblot of control and Hec1 siRNA-depleted HeLa cell lysates. Increasing amounts of lysates are shown, and the blot is probed with the purified rMAb-Hec1 ${ }^{\mathrm{ms}}$ antibody. (G) HeLa cell treated with Hec1 siRNA and stained with the rMAb-Hec $1^{\mathrm{ms}}$ antibody. Cell is also stained with DAPI to detect chromosomes. Scale bars are $10 \mu \mathrm{m}$. 
geneblocks were cloned separately into GFP-N1 vectors with the GFP removed. Signal peptide sequences for each chain (Burton, 1994; Yu et al., 2006) were cloned N-terminal to the heavy chain and light chain sequences to direct the expressed antibody for secretion into the cell media (Figure 1C). The heavy and light chain-containing expression vectors were co-transfected at a ratio of 2:3 (heavy chain:light chain) into $30 \mathrm{~mL}$ cultures of human HEK293 cells grown in suspension (Expi293F cells) using PEI transfection reagent (Figure 1C). The cell supernatant was collected five days post-transfection, and the antibody was purified on a Protein A Sepharose column (Figure 1C). From $30 \mathrm{~mL}$ cell suspension cultures, purification yields of the recombinant Hec1 antibody ( $\mathrm{rMAb}-\mathrm{Hec}{ }^{\mathrm{ms}}{ }^{\text {) }}$ ranged from $0.5-1.4 \mathrm{mg}$ of purified antibody (Figure 1D). To test the quality and specificity of $r M A b-H e c 1^{m s}$, we carried out immunofluorescence staining and found that in HeLa cells, rMAb-Hec $1^{\mathrm{ms}}$ recognized kinetochores during all phases of mitosis, as expected (Figure 1E). We also analyzed mitotic cell lysates from control cells and cells treated with Hec1 siRNA by immunoblotting, and as shown in Figure $1 \mathrm{~F}, \mathrm{rMAb}-\mathrm{Hec} 1^{\mathrm{ms}}$ recognized a single band at $\sim 72 \mathrm{kDa}$ (corresponding to the predicted mass of the 642 amino acid protein, $73.9 \mathrm{kDa}$ ) in control lysates, but not in lysates depleted of Hec1. Consistently, rMAb-Hec1 ${ }^{\mathrm{ms}}$ antibodies did not recognize kinetochores in cells treated with Hec1 siRNA (Figure 1G).

We implemented a similar strategy for generating a recombinant phospho-specific antibody to a conserved, repeating four amino acid motif ("MELT" motif) in the kinetochore scaffolding protein KNL1 whose phosphorylation at the threonine $(T)$ residue by the mitotic kinase Mps1 is required to recruit a suite of spindle assembly checkpoint proteins to kinetochores (Shepperd et al., 2012; Yamagishi et al., 2012; London et al., 2012), and a recombinant antibody to CENP-C, an inner kinetochore protein required for kinetochore assembly (Kixmoeller et al., 2020; Hara and Fukagawa, 2020; Navarro and Cheeseman, 2021). The KNL1 pMELT monoclonal antibody (Fisher Scientific) was generated in rabbit against a peptide containing phosphorylated Thr943 and phosphorylated Thr1155 (Nijenhuis et al., 2014). Sequence results revealed that the PMELT rabbit antibody belongs to class IgG with a kappaclass light chain (Supplemental Figure 1A). The CENP-C monoclonal antibody was generated in mice (Abcam), and sequencing identified the heavy chain as $\lg G 2 b$, and the light chain as belonging to the kappa class (Supplemental Figure 1B). Both the pMELT and CENP-C antibody heavy and light chains were cloned into expression vectors as described for the rMAb-Hec1 ${ }^{\mathrm{ms}}$ antibody. Expression plasmids were transfected into human Expi293F cells, and the antibodies were purified on Protein A Sepharose columns. Immunofluorescence experiments revealed that the rMAb-pMELT ${ }^{\mathrm{rb}}$ antibody recognized kinetochores, and as expected, staining was high at kinetochores in early mitosis and decreased as chromosomes aligned at the spindle equator (Figure 2A) (Nijenhuis et al., 2014; Vleugel et al., 2015).

161 To test the phospho-specificity of the rMAb-pMELT ${ }^{r b}$ antibody, we treated cells with $10 \mu M$ reversine, 162 an Mps1 kinase inhibitor (Santaguida et al., 2010), and found the antibody reactivity was significantly 

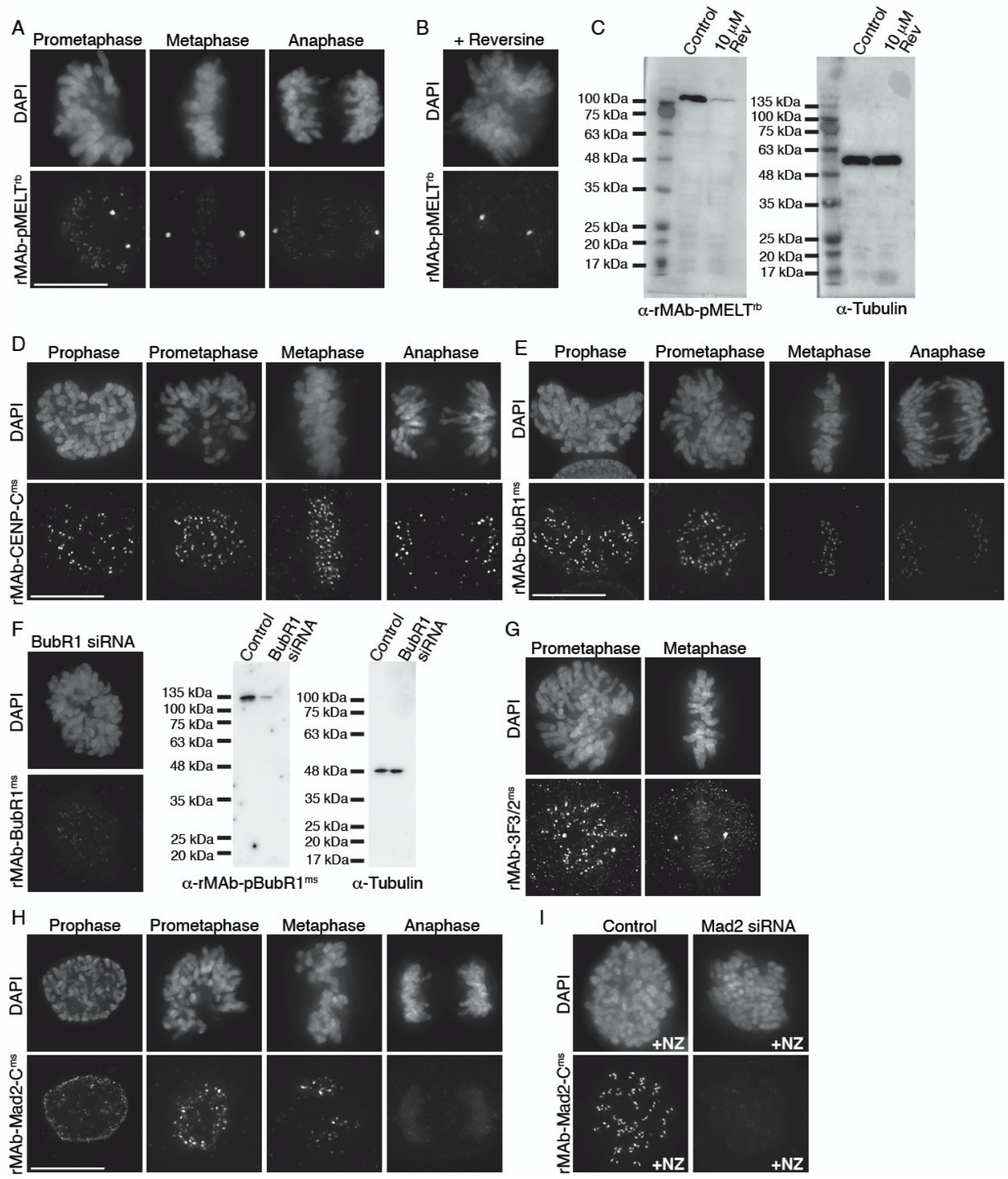

Figure 2. Characterization of recombinant antibodies to KNL1 pMELT, CENP-C, BubR1, 3F3/2 antigen, and Mad2-C. (A) HeLa cells immunostained with rMAb-pMELT ${ }^{\mathrm{rb}}$ antibodies. (B) HeLa cell treated with $10 \mu \mathrm{M}$ reversine and immunostained with rMAb-pMELT' ${ }^{\text {rb }}$ antibodies. (C) Immunoblots of lysates generated from untreated or reversine-treated HeLa cells expressing a $100 \mathrm{kDa}$ fragment of KNL1 containing multiple pMELT domains, and probed with rMAb-pMELT' ${ }^{\mathrm{rb}}$ antibodies (left) and tubulin antibodies as a loading control (right).

(D) HeLa cells immunostained with rMAb-CENP-C ${ }^{\mathrm{ms}}$ antibodies.

(E) HeLa cells immunostained with rMAb-BubR1 ${ }^{\mathrm{ms}}$ antibodies. $(F)$ Left: HeLa cell treated with BubR1 siRNA and immunostained with rMAbBubR1 ${ }^{\text {ms }}$ antibodies. Right: Immunoblots of lysates generated from control or BubR1 siRNA-treated HeLa cells and probed with rMAb-BubR1 ${ }^{\text {ms }}$ antibodies (left) and tubulin antibodies as a loading control (right). (G) HeLa cells immunostained with rMAb3F3/2 $2^{\mathrm{ms}}$ antibodies. (H) HeLa cells immunostained with rMAb-Mad2-C ${ }^{\mathrm{ms}}$ antibodies. (I) HeLa cells (+/- Mad2 siRNA) pre-treated with $500 \mathrm{nM}$ nocodazole for $12 \mathrm{hr}$ and immunostained with rMAb-Mad2- $\mathrm{C}^{\mathrm{ms}}$ antibodies. In all immunofluorescence images, cells were stained with DAPI to detect chromosomes. Scale bars are $10 \mu \mathrm{m}$. 
174 reduced upon Mps1 inhibition, as detected by immunofluorescence and immunoblotting (Figure 2B, C). 175 We found that the rMAb-CENP-C ${ }^{\mathrm{ms}}$ antibody also recognized kinetochores during mitosis; however, the 176 antibody exhibited low levels of cross-reactivity with rabbit secondary antibodies (not shown). We 177 therefore cloned a new CENP-C antibody by combining the $\mathrm{rMAb}-\mathrm{Hec} 1^{\mathrm{ms}}$ antibody constant regions with 178 the sequenced CENP-C antibody variable regions. In this case, immunofluorescence experiments 179 revealed that the new rMAb-CENP-C ${ }^{\mathrm{ms}}$ antibody recognized kinetochores at all phases in mitosis as 180 expected (Hara and Fukagawa, 2020) (Figure 2D), and there was no cross-reactivity with rabbit 181 secondary antibodies (not shown).

We next wanted to obtain primary sequences and generate recombinant antibodies from existing mouse hybridoma cell lines producing monoclonal antibodies to key mitotic epitopes. To this end, we used cell lines expressing antibodies to the following targets: (1) the kinetochore-associated and spindle assembly checkpoint protein BubR1 (Chan et al., 1999; Zhang et al., 2015; Lischetti and Nilsson, 2015); (2) the 3F3/2 phospho-epitope which recognize kinetochores that are lacking tension from microtubule pulling forces (Gorbsky and Ricketts, 1993; Nicklas et al., 1995; Waters et al., 1998); and (3) the active form of the kinetochore-associated and spindle assembly checkpoint protein Mad2, which recognize the "closed" conformation of Mad2 molecules found in Mitotic Checkpoint Complexes or bound to Mad1 (Sedgwick et al., 2016; De Antoni et al., 2005; Mapelli et al., 2007). For each hybridoma cell line, the mRNA transcriptome was obtained and used to generate a cDNA library from which the antibody sequences were identified through whole transcriptome shotgun sequencing (Absolute Antibody; Boston, MA). Based on the obtained sequences, the antibodies were classified as follows: BubR1: IgG2b / kappa light chain; 3F3/2: IgG2a / kappa light chain; and Mad2-Closed (Mad2-C): IgG1 / kappa light chain (Supplemental Figure 2A-C). Through this approach, we were able to additionally obtain the sequences of the native $\mathrm{N}$-terminal signal peptides (also referred to as leader peptides) for both heavy and light chains for all three antibodies (Supplemental Figure 2A-C). Heavy and light chain sequences were cloned into expression vectors as described for $\mathrm{rMAb}-\mathrm{Hec} 1^{\mathrm{ms}}$ above, with the exception that the native signal peptides were used. Expression plasmids were transfected into human Expi293F cells, and the antibodies were purified on Protein A Sepharose columns. Immunofluorescence experiments revealed that all three antibodies recognized kinetochores during mitosis (Figure 2E, G, and $\mathrm{H}$ ). As expected, staining for all antibodies was high at kinetochores in early mitosis and decreased as chromosomes aligned at the spindle equator (Skoufias et al., 2001; Hoffman et al., 2001; Campbell and Gorbsky, 1995) (Figure 2E, G, and H). To test the specificity of rMAb-BubR1 ${ }^{\mathrm{ms}}$, HeLa cells were treated with an siRNA targeted to BubR1 and processed for immunofluorescence or immunoblotting. As shown in Figure 2F, cells depleted of BubR1 exhibited significantly reduced reactivity with rMAb-BubR1 ${ }^{\mathrm{ms}}$ antibodies at kinetochores (left), or in cell lysates (right). Similarly, HeLa cells treated with Mad2 siRNA exhibited no reactivity at kinetochores with rMAb-Mad2- $\mathrm{C}^{\mathrm{ms}}$ antibodies (Figure 2I). In this case, cells were treated with 
210 nocodazole to enrich for kinetochore-association of Mad2, which is rapidly evicted from kinetochores in

211 the presence of spindle microtubules in untreated cells.

\section{Modification of antibody species specificity}

214 For indirect immunofluorescence experiments, a commonly used cell biology approach, a fluorescently 215 tagged secondary antibody recognizes a primary antibody and provides signal detection and 216 amplification. In many cases, commercial primary antibodies directed to target antigens are only available 217 in a single animal specificity, meaning the antibodies were generated in a particular species and contain 218 heavy and light chain constant regions unique to that species. In practice, this limits the number and 219 combinations of targets that can be probed for and detected in such experiments. A solution to this problem is to directly conjugate primary antibodies with fluorescent dyes, obviating the need for secondary antibodies, and allowing for the simultaneous use of two primary antibodies generated in the same host species. However, this approach requires a substantial amount of primary antibody, which may be cost prohibitive if the antibodies are purchased from a commercial source. Furthermore, this approach eliminates secondary antibody-mediated amplification of primary antibody signals. We therefore set out to alter the species specificity of our recombinant monoclonal antibodies to expand our
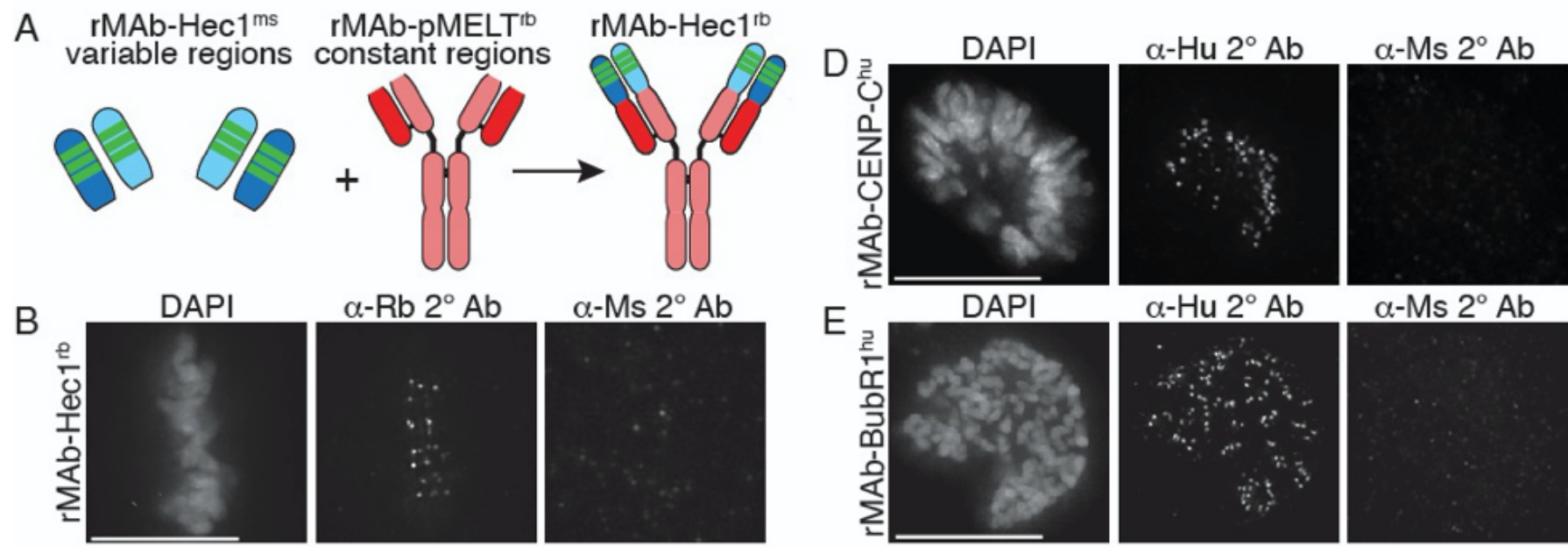

$\alpha-\mathrm{Ms} 2^{\circ} \mathrm{Ab}$
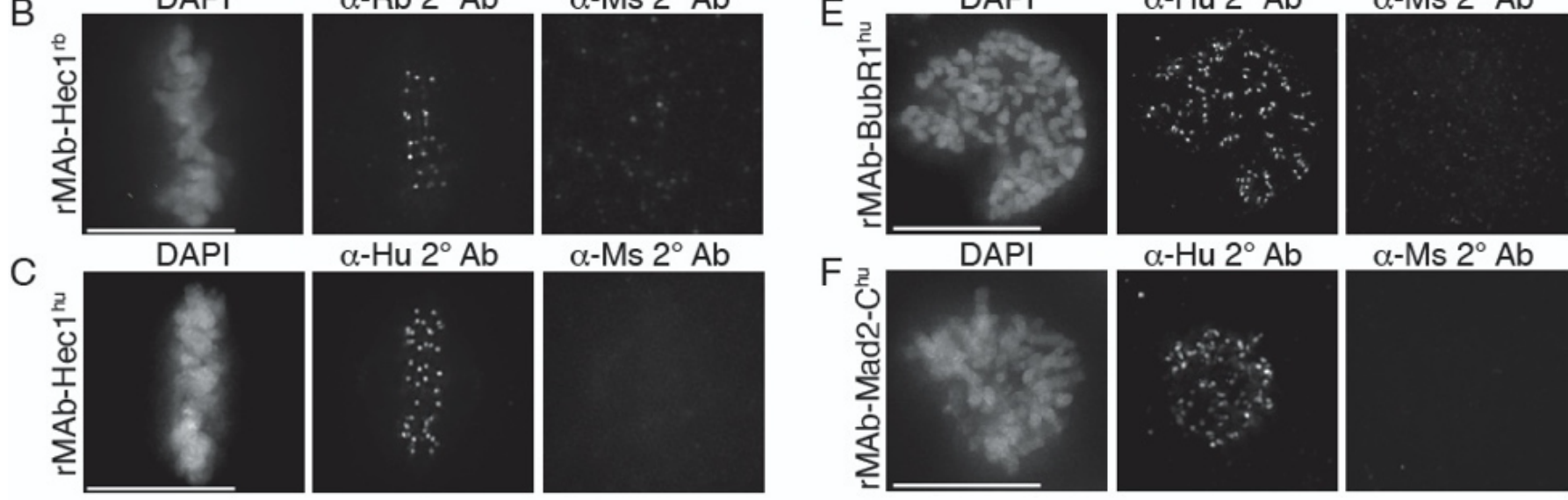

$\alpha-\mathrm{Ms} 2^{\circ} \mathrm{Ab}$

Figure 3. Generation of recombinant antibodies with modified species specificity. (A) Schematic of "species swap" approach. (B-F) HeLa cells stained with antibodies to rMAb-Hec $1^{\text {rb }}$, panel B; rMAb-Hec $1^{\text {hu }}$, panel C; rMAb-CENP-C ${ }^{\text {hu }}$, panel D; rMAb-BubR1 ${ }^{\text {hu }}$, panel E; and rMAb-Mad2- $C^{\text {hu }}$, panel F. For all panels B-F, cells were probed with the species-appropriate secondary antibody and also with secondary antibodies specific for the original species. Cells were also stained with DAPI to detect chromosomes. Scale bars are $10 \mu \mathrm{m}$. 
232 toolbox of available reagents. To this end, we generated a new Hec1 primary antibody, termed rMAb-

$233 \mathrm{Hec}^{\mathrm{rb}}$, such that it is recognized by a rabbit secondary antibody. We generated the new sequence by

234 removing the constant regions from both the heavy and light chains of the rMAb-Hec $1^{\text {ms }}$ antibody and

235 replacing them with the constant regions from a rabbit IgG antibody (Figure 3A). The new heavy and

236 light chain expression plasmids were transfected into human Expi293F cells and purified on a Protein $A$

237 Sepharose column as described above. We tested the antibody in immunofluorescence assays and

238 determined that the $\mathrm{rMAb}-\mathrm{Hec} 1^{\mathrm{rb}}$ localized to kinetochores in mitotic cells, and importantly, was

239 recognized by rabbit secondary antibodies, but not by mouse secondary antibodies. (Figure 3B). We

240 diversified the Hec1 antibody even further by generating a version that is recognized by a human

241 secondary antibody. In this case, we acquired human IgG amino acid sequences from the UniProt

242 Knowledgebase (UniProt \# P01857 and P01834) and generated geneblocks for the heavy and light chain

243 constant regions. We then combined the variable regions of both the heavy and light chains from the

$244 \mathrm{rMAb}-\mathrm{Hec}^{\mathrm{ms}} \lg 2 \mathrm{2a}$ sequence with the human $\mathrm{IgG}$ antibody constant sequences to generate plasmids

245 encoding for $\mathrm{rMAb}-\mathrm{Hec}^{\text {hu }}$ (Figure $3 \mathrm{C}$ ). We purified and tested this antibody in immunofluorescence

246 assays and determined that the $\mathrm{rMAb}-\mathrm{Hec} 1^{\text {hu }}$ localized to kinetochores in mitotic cells, and was

247 recognized by human, but not mouse secondary antibodies (Figure 3C). We went on to use this approach

248 to generate a number of additional species variants, including rMAb-Cenp-C ${ }^{\text {hu }}$, rMAb-Mad2- $C^{\text {hu }}$, and

249 rMAb-BubR1 ${ }^{\text {hu }}$ antibodies (Figure 3D-F).

251 Generation of recombinant antibody fragments

252 For some cell biological and biomedical applications, antibody fragments, generated by either proteolysis 253 or genetic engineering, offer advantages over the use of intact, bivalent antibodies. For example, their 254 smaller size allows more efficient penetration of tissue samples and may provide better access to "buried" 255 epitopes; they are able to bind targets without inducing cross-linking; they reduce steric effects (compared 256 with intact antibodies) when monitoring an antigen in living cells, and they have reduced immunogenicity, 257 which may be desirable for therapeutic applications (Hayashi-Takanaka et al., 2011; Cheloha et al., 2020; 258 Zhao et al., 2019; Xenaki et al., 2017; Berland et al., 2021; Ries et al., 2012; Morisaki et al., 2016; Yan 259 et al., 2016; Wang et al., 2016; Stasevich et al., 2014). Another advantage is that single chain antibody 260 fragments can be fused to a fluorescent protein and genetically encoded for expression in living cells for 261 the purpose of real-time antigen tracking. This ability becomes particularly important when an antibody 262 recognizes a post-translational protein modification or specific protein conformation, which cannot be 263 tracked simply by expressing a fluorescently-tagged version of a protein of interest (Sato et al., 2013; 264 Kimura et al., 2015). Finally, the use of antibody fragments is becoming increasingly important in super265 resolution microscopy approaches, where the achieved spatial resolution depends not only on the 266 imaging method, but on the size of the probes used (Ries et al., 2012; Traenkle and Rothbauer, 2017; 267 Mikhaylova et al., 2015; Zhao et al., 2019). 
To further diversify our recombinant antibodies and to capitalize on the advantages listed above, we set out to generate three types of antibody fragments: (1) scFvC (single chain variable plus a truncated constant region), (2) scFv (single chain variable fragment), and (3) Fab (antigen binding fragment). We

272 first used the antibody sequences to Hec1 and Mad2-C to generate recombinantly expressed and purified
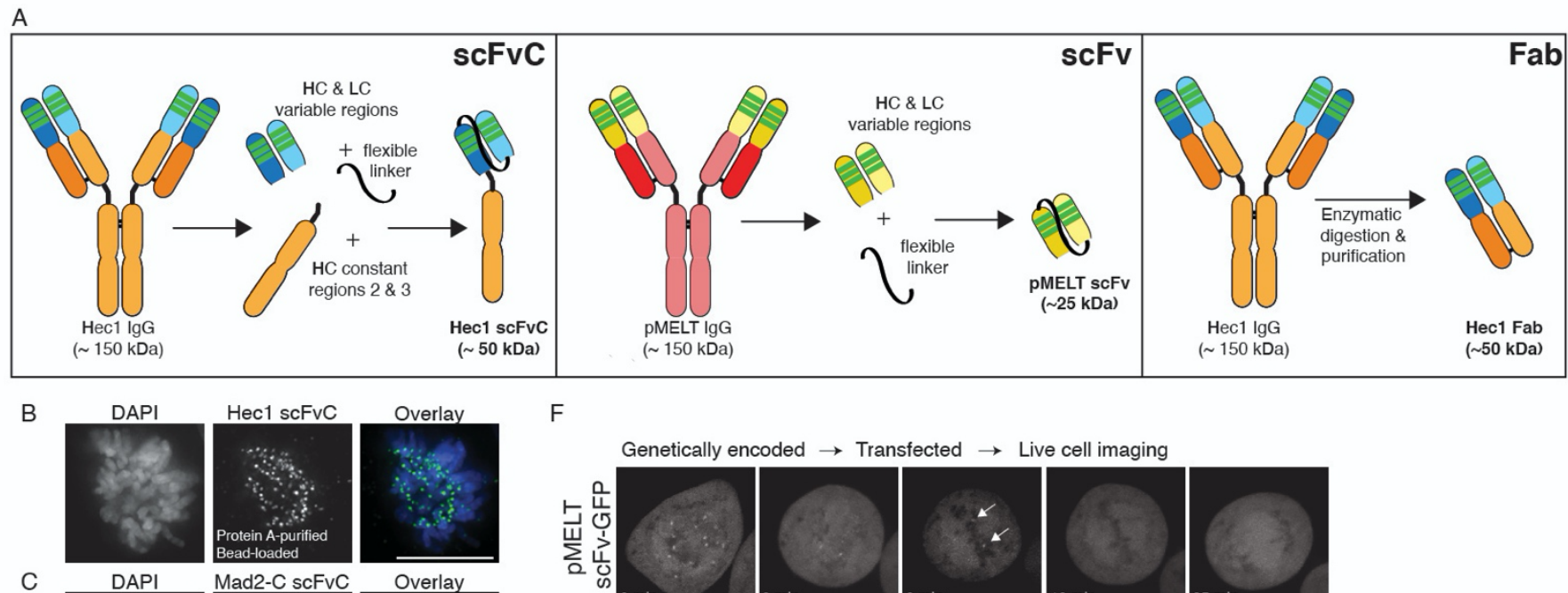

F

C

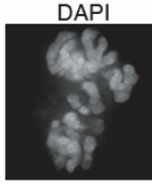

D
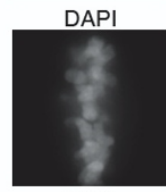

E

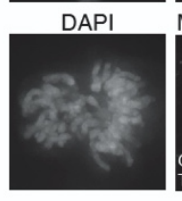

Mad2-C scFvC

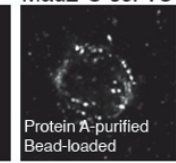

Hec1 scFvC

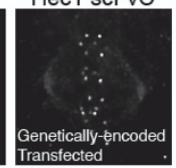

Mad2-C scFvC

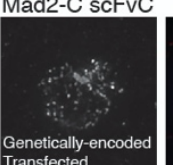

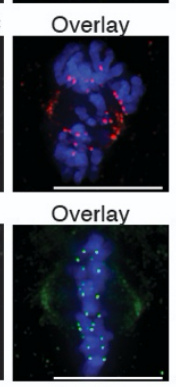

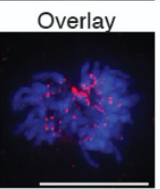

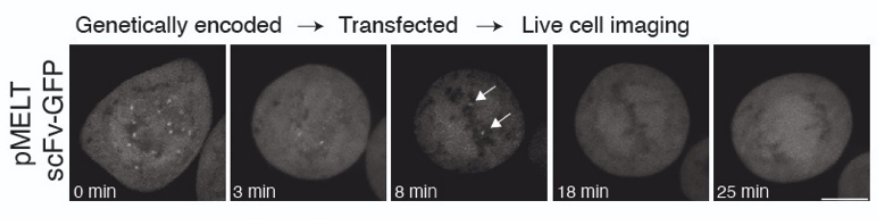

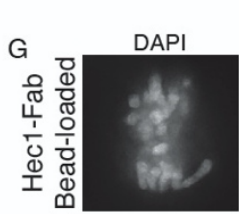

Hec1 Fab-

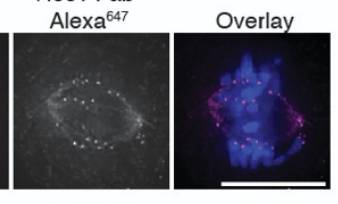

$\mathrm{H}$

Hec1 Fab- Hec1 Fab-
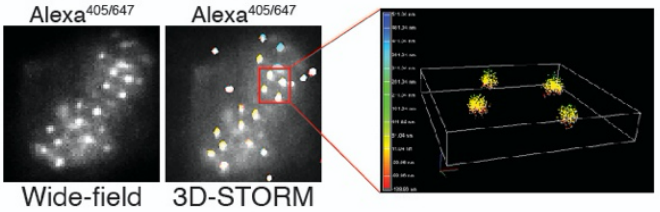

Figure 4. Generation of antibody fragments. (A) Schematic illustrating the generation of three types of fragments: scFvC (left), scFv (center), and Fab (right). (B and C) Hec1 and Mad2-C scFvC fragments were purified on Protein A Sepharose columns and bead-loaded into HeLa cells. Cells were fixed and stained with anti-rabbit secondary antibodies and DAPI to detect chromosomes. (D and E) HeLa cells were transfected with the scFvC-Hec1 plasmid or the scFvC-Mad2-C plasmid. Cells were fixed and stained with anti-rabbit secondary antibodies and DAPI to detect chromosomes. $(F)$ HeLa cells were transfected with the scFv-pMELT-GFP plasmid and time-lapse imaged using confocal microscopy, and a representative cell is shown. At time $=0$ min, many kinetochores are positive for scFv-pMELT-GFP, and by $18 \mathrm{~min}$, when the cell has reached metaphase, no kinetochore-associated pMELT signals are detected. Arrows in the $8 \mathrm{~min}$ timepoint image point to the kinetochores which retain detectable MELT phosphorylation in late prometaphase. (G) Hec1 Fab were generated through proteolysis and directly labeled with an Alexa 647 fluorophore. HeLa cells were bead-loaded with Hec1 Fab ${ }^{647}$, stained with DAPI to detect chromosomes, and imaged. (H) Hec1 Fab were generated through proteolysis and directly labeled with both Alexa 405 and Alexa 647 fluorophores. HeLa cells were fixed, permeabilized, incubated with Hec1 Fab ${ }^{405 / 647}$, and subjected to both wide-field (left) and STORM imaging (right). Scale bars are $10 \mu \mathrm{m}$. 
scFvC fragments, which contain the variable regions of the heavy and light chains connected by a flexible linker, attached to the rabbit IgG-specific heavy chain constant regions $(\mathrm{CH} 2+\mathrm{CH} 3)$ in a single polypeptide chain and totaling $\sim 50 \mathrm{kDa}$ in mass (Figure 4A, left panel). Single plasmids encoding for the Hec1 and Mad2-C scFvC fragments (scFvC-Hec1 $1^{\text {rb }}$ and scFvC-Mad2- $\mathrm{C}^{\mathrm{rb}}$ ), which include signal peptides (Lima and Cosson, 2019), were transfected into human Expi293F cells and purified on Protein A

293 Sepharose columns. We expressed and were able to purify the scFvC fragments on our affinity columns, 294 since they contain a portion of the heavy chain constant region that is recognized by Protein A. The 295 purified Hec1 and Mad2-C scFvC fragments were introduced into cells by bead-loading (McNeil and 296 Warder, 1987; Cialek et al., 2021), and the cells were subsequently fixed and incubated with anti-rabbit secondary antibodies. As shown in Figure 4B and 4C, the fragments recognized kinetochores in mitotic cells, and the results were similar to those obtained with the intact, bivalent antibodies. Next, we generated genetically encoded ScFvC fragments using both the Hec1 and Mad2-C antibody sequences. For these constructs, we removed the signal peptide sequence and transiently expressed a single plasmid encoding for the heavy and light chain variable regions connected by the flexible linker, and the rabbit lgG-specfic heavy chain constant regions $(\mathrm{CH} 2+\mathrm{CH} 3)$. HeLa cells were transfected with the single plasmids, prepared for immunofluorescence and stained with an anti-rabbit secondary antibody, and as shown in Figure 4D and E, the genetically encoded Hec1 and Mad2-C scFvC fragments both recognized kinetochores in mitotic cells.

We next used the rMAb-pMELT ${ }^{\mathrm{rb}}$ sequence to generate an ScFv, comprised of the variable regions of the heavy and light chains connected by a flexible linker and totaling $\sim 25 \mathrm{kDa}$ in mass (Figure 4A, middle panel). In this case, the scFv does not contain the Fc (fragment crystallizable) region (comprised of the heavy chain constant regions CR2 and CR3), which is recognized by Protein A. We therefore did not express and purify the antibody for this experiment. However, we added a GFP tag to the C-terminus of the polypeptide chain, omitted the signal peptide, and expressed the fluorescently tagged scFv in HeLa cells. We collected time-lapse images, and as shown in Figure 4F, the genetically encoded pMELT scFvGFP recognizes kinetochores in early mitosis when phosphorylation of the KNL1 MELT repeats is high, but much less so in late mitosis, when phosphorylation of the MELT repeats is low. These results demonstrate that small immunological probes can be generated from primary monoclonal antibody sequences and successfully expressed in mitotic cells to detect mitotic antigens, and importantly, posttranslational protein modifications of mitotic targets in living cells.

Finally, we used the recombinant, purified $\mathrm{rMAb}-\mathrm{Hec} 1^{\mathrm{ms}}$ antibody to generate antigen binding fragments (Fab), containing a single constant region of each chain and the variable regions from both the heavy and light chains (Figure 4A, right panel). The purified rMAb-Hec1 ${ }^{\mathrm{ms}}$ antibody was enzymatically digested with papain protease, the digestion reaction was centrifuged through a Protein $A$ spin column, and the 
antigen binding fragments, which do not bind the Protein A resin, were collected in the flow through. We directly labeled the $\mathrm{rMAb}-\mathrm{Hec} 1^{\mathrm{ms}} \mathrm{Fab}$ with an Alexa 647 fluorescent dye and bead-loaded the fragment into HeLa cells, and as shown in Figure 4G, the labeled Fab recognizes kinetochores in mitotic cells. We next tested if the labeled $\mathrm{rMAb}-\mathrm{Hec}{ }^{\mathrm{ms}} \mathrm{Fab}$ is appropriate for use in super-resolution STORM imaging. For this experiment, we double-labeled the rMAb-Hec1 ${ }^{\mathrm{ms}}$ Fab with Alexa 647 and Alexa 405 dyes at a ratio of $1: 1$. HeLa cells were then fixed and stained with the dually-labeled rMAb-Hec1 ${ }^{\mathrm{ms}}$ Fab $^{405 / 647}$ fragment (Figure 4H). Samples were excited with 405 and $640 \mathrm{~nm}$ lasers, and images were collected on a Nikon N-STORM imaging system. The Fab robustly recognized kinetochores and the resulting STORM images demonstrate that our recombinantly expressed antibody fragments are compatible with superresolution imaging approaches (Figure $4 \mathrm{H}$ ). Importantly, these super-resolution techniques benefit from the use of small, directly labeled probes by preventing loss of spatial resolution that occurs with the use of larger, intact bivalent primary and secondary antibodies (Ries et al., 2012; Traenkle and Rothbauer, 2017; Mikhaylova et al., 2015).

\section{Reverse engineering antibody fragments into full-length, bivalent antibodies}

Advances in genetic engineering techniques such as antibody phage display and hyper-variable domain grafting have provided new routes to generating antibody fragments including ScFv (single-chain variable fragments) and single-domain antibodies (sdAbs, also known as nanobodies) (Panikar et al., 2021; Laustsen et al., 2021; Valldorf et al., 2021; Shim, 2017; Shukra et al., 2014; Zhao et al., 2019). As a result, there are growing numbers of published antibody fragment sequences. As discussed above, there are numerous advantages to using such antibody fragments; however, there are also cases in which a full-length, bivalent antibody is preferred. For example, in standard indirect immunofluorescence experiments, multiple secondary antibodies bind to the constant regions of a full-length, bivalent primary antibody, which results in signal amplification and increased sensitivity. Similar arguments can be made for the use of full-length, bivalent antibodies in immunoblotting and immunoprecipitation experiments. Given the rise in availability of antibody fragment sequences, we wanted to use our approach to convert scFv sequences into full-length, bivalent antibodies. For this reason, we modified an HA (hemagglutinin)tag scFv (also known as the HA-tag "frankenbody") sequence (Zhao et al., 2019) into a full-length, bivalent antibody. Specifically, we cloned the heavy chain variable regions of the HA-tag scFv onto the heavy chain constant regions from a rabbit lgG antibody (Figure 5A). Similarly, we cloned the light chain variable region of the HA-tag scFv onto the rabbit lgG light chain constant region (Figure 5A). In addition, signal peptides were cloned into both heavy and light chain plasmids. Both plasmids were transfected into human Expi293F cells as described above and full-length, bivalent antibody secreted into the cell media was purified using a Protein A Sepharose column. To test the antibody in cells and to confirm specificity, we expressed the following versions of Hec1 in HeLa cells: HA-tagged (Figure 5B); HA- and GFP-tagged (Figure 5C), and GFP-tagged (Figure 5D). Cells were prepared for immunofluorescence and 
stained with the rMAb-HA ${ }^{\mathrm{rb}}$ antibody and a fluorescently-labeled rabbit secondary. As shown in Figure 5

361 B-D, the rMAb-HA ${ }^{\text {rb }}$ antibody recognized Hec1 at kinetochores in cells expressing Hec1-HA and Hec1-

362 HA-GFP, but not in cells expressing Hec1-GFP.

A

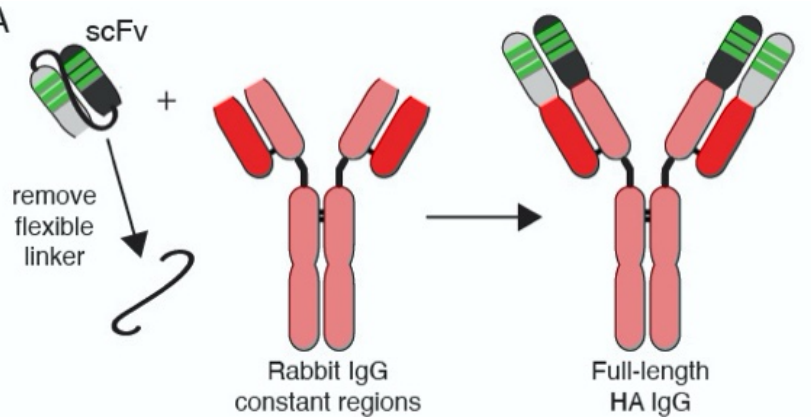

B

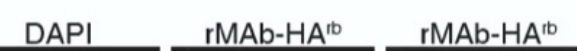
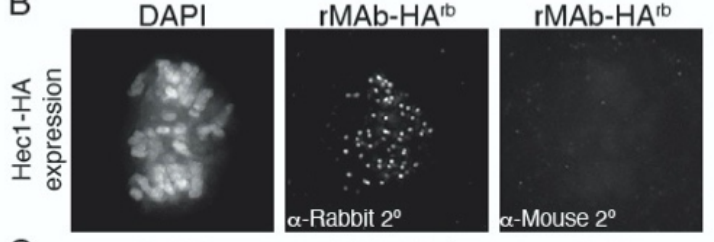

C DAPI

rMAb-HA'
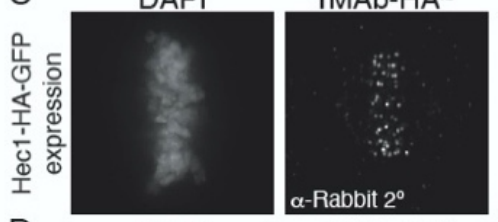

GFP

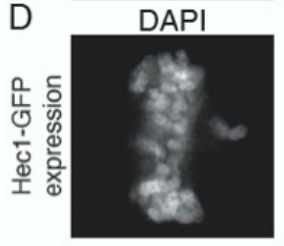

$r M A b-H A^{r b}$

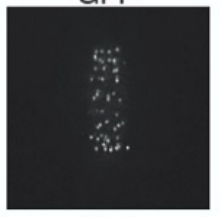

E

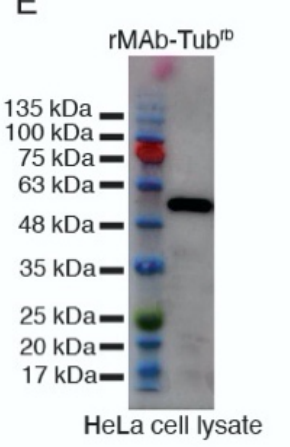

$\mathrm{F}$
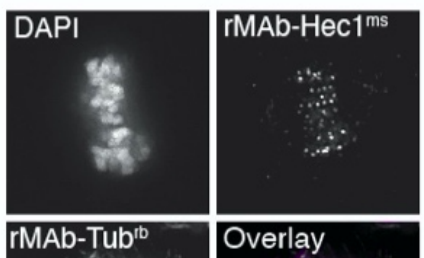

Overlay
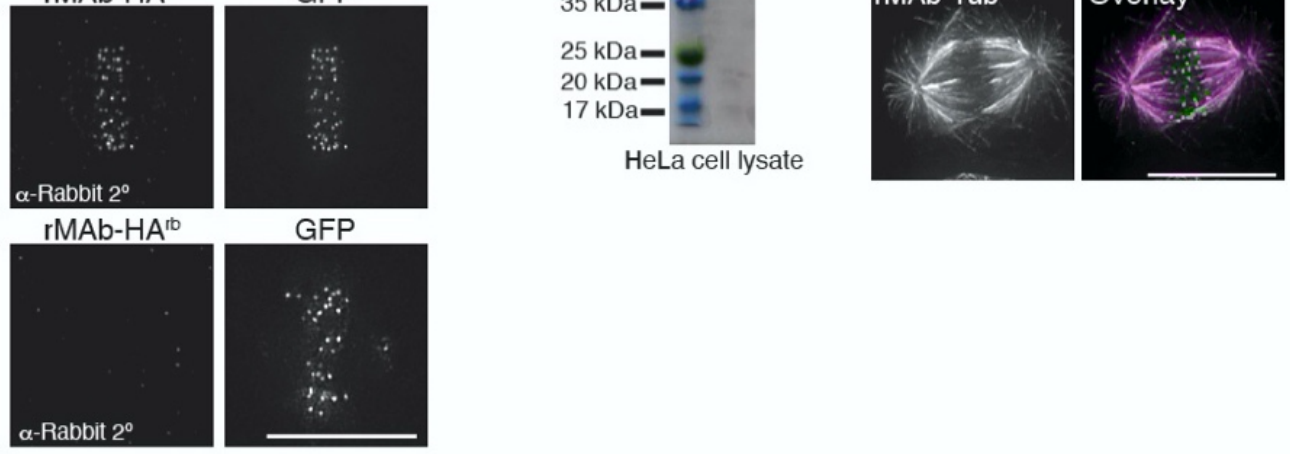

GFP

Figure 5. Generation of full-length, bivalent antibodies from fragment sequences. (A) Schematic illustrating the generation of a reverse engineered, full-length HA-tag antibody from an ScFv. (B-D) HeLa cells were transfected with Hec1-HA (B), Hec1HA-GFP (C), or Hec1-GFP (C), and immunostained with rMAb-HA ${ }^{r b}$ antibodies. In panels $C$ and D, GFP was imaged. (E) Immunoblot of HeLa lysate probed with reverse engineered, full-length tubulin antibody, rMAb-Tubrb. (F) HeLa cells immunostained with rMAb-Hec $1^{\mathrm{ms}}$ and $\mathrm{rMAb}-\mathrm{Tub}^{\mathrm{rb}}$. In all immunofluorescence images, cells were stained with DAPI to detect chromosomes. Scale bars are $10 \mu \mathrm{m}$.

372 Finally, we carried out a similar reverse engineering approach to generate a full-length, bivalent IgG 373 tubulin antibody using the sequence of an alpha tubulin scFvC antibody fragment (Lima and Cosson, 374 2019). Similar to the approach used for the HA-tag scFv described above, we cloned the heavy and light chain variable regions from the tubulin $\mathrm{ScFvC}$ onto the heavy and light chain constant regions from a rabbit IgG antibody. Additionally, signal peptides were cloned into both the heavy and light chain plasmids. The full-length antibody was expressed and purified from human Expi293F cells. We confirmed that the new, bivalent rMAb-Tub ${ }^{\text {rb }}$ antibody recognized a $\sim 55 \mathrm{kDa}$ protein in HeLa cell lysate, which corresponds to the molecular weight of $\alpha$ and $\beta$ tubulin monomers (Figure 5E). In addition, the antibody 
recognizes microtubules in cells, and as expected, the primary antibody is recognized by rabbit but not mouse secondary antibodies (Figure 5F).

\section{Discussion}

384 Here we describe a set of tools and protocols that can be used to generate high-yield, low-cost antibodies 385 and antibody fragments from primary amino acid sequences. While most of the antibodies and antibody 386 derivatives described here are directed to antigens involved in mitotic cell division and kinetochore 387 function, the plasmids and protocols are applicable to any monoclonal antibody sequence. Using relatively small volumes $(\sim 30 \mathrm{~mL})$ of human Expi293F cells grown in suspension, we demonstrate production of up to $1.4 \mathrm{mg}$ of protein per preparation (rMAb-Hec $1^{\mathrm{ms}}$ ). We note, however, that the yields for individual antibody preparations varied, and our lowest yields were in the range of $0.1 \mathrm{mg}$ of protein from a $30 \mathrm{~mL}$ suspension culture. We have not yet defined the source of yield variation, but we are working to normalize these values by optimizing the cloning, expression, and purification conditions for the lower-yield reagents.

In some cases, the major cost incurred for the approach described here is the protein sequencing itself. Currently, the approximate costs of sequencing a purified monoclonal antibody ranges from $\sim \$ 5000$ $\$ 12,000$. However, obtaining sequence information from a monoclonal hybridoma cell line is much less expensive ( $\$ 500-\$ 1500)$, and is offered through many companies and non-profit facilities as a standalone service, or as an "add-on" cost for custom monoclonal antibody production services. We propose that if individual research labs submit existing hybridoma cell lines for antibody sequencing and share this information publicly, this would greatly benefit the entire research community by providing a means for individual labs to produce low-cost antibodies and generate customized reagents for use in their own research. Importantly, there are growing numbers of available monoclonal antibody sequences available through databases, obtained through protein sequencing or from atomic structures. These include the ABCD (Antibodies Chemically Defined) database at the Geneva Antibody Facility (Lima et al, 2000); https://web.expasy.org/abcd); the ABG (Antibody Group) directory

407 (http://pt7mdv.ceingebi.unam.mx/vir/structure/structures.html); the Kabat database (Johnson and Wu, 408 2000); $\quad$ http://bigd.big.ac.cn/databasecommons/database/id/5425); $\quad$ SAbDab 409 (http://opig.stats.ox.ac.uk/webapps/newsabdab/sabdab/); abYbank (www.abybank.org); and the IMGT 410 (International Immunogenetics Information System) monoclonal antibodies database 411 (http://www.imgt.org/mAb-DB/doc). The approaches described are intended to facilitate the expression 412 and purification of recombinant antibodies and antibody fragments in individual labs using accessible, 413 non-specialized equipment and reagents; however, we note that many non-profit, institutional core 414 facilities also offer these services at relatively low costs, which provide a convenient and accessible alternative to expressing and purifying antibodies in-house. We also note that costs can be reduced by 
416 ordering geneblocks for only the variable regions of a newly sequenced antibody and combining these

417 sequences with previously-validated constant regions of choice (e.g. those described here for rabbit, 418 mouse, and human IgG antibodies). Finally, it is important to consider downstream usage of data 419 generated from antibodies purchased from commercial sources, as different companies may have unique 420 sets of terms and conditions.

422 In addition to providing low-cost methods for in-house monoclonal antibody production, the approaches 423 described here allow for diversification of sequenced monoclonal antibodies. One practical example of 424 such diversification is altering the species specificity by "swapping" constant regions. Researchers are typically limited to the combination of antigens they wish to detect in indirect immunofluorescence or immunohistochemical experiments by species specificity of the antibodies. Once a monoclonal antibody sequence is in hand, it is simple and straightforward to produce a new antibody containing the constant regions specific to a different species.

Another advantage of the methodology described here is the ability to generate antibody fragments from a primary sequence. Advantages of such fragments include more efficient penetration of tissue and cell samples; access to less-accessible epitopes; the ability to bind targets without inducing cross-linking; and reduced steric effects compared with full-length bivalent antibodies. Additionally, antibody fragments can be used for tracking protein modifications and specific protein conformations in living cells. To study protein dynamics in cells, fluorescent proteins such as GFP are typically fused to a protein of interest, expressed, and monitored in living cells. However, such fluorescent protein tags cannot track or identify protein modifications (e.g. phosphorylation), nor can they detect specific protein conformations, both of which may play critical roles in a protein's cellular function. In recent years, fluorescently labeled antibody fragments such as Fab, scFv, scFvC, and nanobodies have been used for the purpose of tracking posttranslational modifications and specific protein conformations (Kimura et al., 2015; Lyon and Stasevich, 2017; Sachs et al., 1972). Antibody fragments may be preferable to intact bivalent antibodies for tracking modifications and specific conformations in living cells since their smaller size minimizes steric effects of the probes themselves, which could lead to interference with protein function. Such antibody fragments can be purified, directly labeled with a fluorescent dye, and introduced into cells by microinjection, electroporation, or bead-loading, and visualized in living cells. Alternatively, single chain antibody 446 fragments (e.g. scFv, scFvC) fused to a fluorescent protein such as GFP can be genetically encoded for 447 expression and monitoring in living cells. Here, we describe tools to generate both types of labeled 448 antibody fragments from a primary monoclonal antibody sequence, which will allow for investigations of 449 processes in cells that have previously not been feasible. For example, during mitotic cell division the 450 regulation of kinetochore-microtubule attachments is driven in large part by reversible and dynamic 451 phosphorylation events, yet these events have not yet been monitored in real-time during mitotic 
452 progression in living cells. The methodologies described here will enable the generation of reagents for

453 real-time tracking of phosphorylation events on key kinetochore proteins during chromosome 454 congression and spindle assembly checkpoint inactivation, which will provide critical insight into the 455 mechanisms that regulate kinetochore function during mitosis.

457 It is important to note that while we were successful in generating a recombinant scFv directed to the 458 KNL1 pMELT domain using the native sequence, we were not successful in generating scFv fragments 459 to Hec1, BubR1, or Mad2-C. Why this is the case is not clear; however, there are other methods to obtain 460 an scFv from the primary sequence that we have not yet explored. For example, it has been demonstrated 461 that the hyper-variable domains, obtained from the primary sequence of a monoclonal antibody, can be 462 grafted onto optimized scFv scaffolds which are known to function in cells (Zhao et al., 2019). This 463 approach has led to the generation of genetically encoded single chain antibody fragments referred to as 464 "frankenbodies," which are capable of recognizing and tracking specific epitopes in cells (Zhao et al., 465 2019).

In this study, we also demonstrated that our recombinant antibody fragments can be directly labeled with fluorescent dyes for use in super-resolution light microscopy approaches. The use of small, directlylabeled probes is desirable for super-resolution imaging approaches, such as PALM/STORM, where the goal is precise molecular mapping of antigens on the nanometer scale. The size of the probe is directly relevant since larger probes, such as intact, bivalent primary and secondary antibodies, will limit the achievable resolution (Ries et al., 2012; Traenkle and Rothbauer, 2017; Mikhaylova et al., 2015). For example, an intact bivalent antibody is approximately 10-15 $\mathrm{nm}$ long, and when using an imaging technique with a spatial resolution in the range of 20-30 nm (e.g. STED; PALM/STORM), such a large labeling probe reduces the resolution by approximately 2 -fold.

In summary, we describe methodologies to generate and purify recombinant versions of a suite of antibodies directed to kinetochore and mitotic proteins. We also present a set of molecular biological methods to expand the versatility of these antibodies by altering species specificity and generating antibody fragments that can be either genetically encoded for tracking antigens in cells or recombinantly expressed and purified. As tools such as these become more widely shared, access to low-cost, sequence-defined antibodies will increase, benefiting all fields that utilize antibody and antibody-based tools.

\section{Materials and Methods}

Antibody sequencing. Purified samples (100 $\mu \mathrm{g}$ each) of Hec1 (Genetex), KNL1 pMELT (Fisher 
488 Ontario, Canada) using tandem mass spectrometry. Data obtained from these antibodies presented in 489 the current study are for non-commercial purposes only, in accordance with the terms and conditions of 490 the companies from which the CENP-C, Hec1 9G3, and KNL1 pMELT antibodies were purchased. Cell 491 samples $\left(10^{6}\right.$ cells each) of Mad2, BubR1, and 3F3/2 hybridoma cell lines were submitted to Absolute 492 Antibody (Boston, MA, USA) for sequencing. For each cell sample, the mRNA transcriptome was 493 obtained through whole transcriptome shotgun sequencing, the resulting reads were assembled into 494 contigs, and antibody transcripts were identified based on homology.

Plasmid generation. For full-length Hec1, KNL1 pMELT, CENP-C, Mad2-C, BubR1, and 3F3/2 antibodies, the protein sequence for each was used to design DNA geneblocks optimized for expression in human cells using the IDT (Integrated DNA Technologies) codon optimization tool. For full-length Hec1, KNL1 pMELT, and CENP-C antibodies, an N-terminal signal peptide sequence was added to the geneblock (Burton, 1994; Yu et al., 2006). For Mad2-C, BubR1, and 3F3/2 antibodies, the native signal peptides were included in the geneblock design. The resulting DNA fragments/geneblocks were cloned using the Gibson assembly method into the pEGFP-N1 vector (Clontech) with the GFP removed by Sac1/Not1 digestion, henceforth referred to as the rMAbParent plasmid. For each full-length antibody, a heavy chain (HC) and light chain (LC) plasmid was generated for co-expression in HEK293 suspension culture cells (Expi293F cells) (Fisher Scientific). For species specificity swapping experiments, geneblocks corresponding only to the variable regions of the HCs and LCs were designed and ordered. PCR fragments were generated corresponding to the target species constant regions for both HCs and LCs. DNA fragments from the geneblocks for the variable regions were combined with the PCR fragments for the constant regions and cloned into the rMAbParent plasmid using the Gibson assembly method. For construction of each of the Mad2 and Hec1 scFvC plasmids, the following PCR fragments were generated: (1) HC variable region (for expression in Expi293F cells, a signal peptide was also included;

512 for genetic encoding, the signal peptide was not included) (Sasada et al., 1988), (2) flexible linker, (3) LC 513 variable region, and (4) rabbit IgG $\mathrm{HC}$ constant regions $(\mathrm{CH} 2$ and $\mathrm{CH} 3)$. PCR fragments were cloned by 514 the Gibson assembly method into the rMAbParent plasmid resulting in a final single scFvC plasmid. For 515 construction of the KNL1 pMELT scFv, the following PCR fragments were generated: (1) HC variable 516 region (for expression in Expi293F cells a signal peptide was also included; for genetic encoding, the 517 signal peptide was not included) (Sasada et al., 1988), (2) flexible linker, and (3) LC variable region. PCR 518 fragments were cloned by the Gibson assembly method into the rMAbParent plasmid (containing the 519 sequence for GFP), resulting in a final single scFv plasmid. To generate the full-length bivalent HA-tag 520 antibody, PCR fragments were generated corresponding to the $\mathrm{HC}$ and LC variable regions of the $\mathrm{HA}$ 521 tag scFv, which were generated by grafting the HA-tag HC and LC hyper-variable regions (a.k.a. 522 complementarity determining regions or CDRs) into the 15F11 scaffold (Zhao et al., 2019). The PCR 523 fragments containing the $\mathrm{HC}$ and LC variable regions also included $\mathrm{N}$-terminal signal peptide sequences 
524 (Burton, 1994; Yu et al., 2006). PCR fragments corresponding to the rabbit IgG-specific LC and HC 525 constant regions were generated and, together with the $\mathrm{HC}$ and LC variable regions, were cloned into 526 the rMAbParent plasmid using the Gibson assembly method. To generate the full-length bivalent tubulin 527 antibody, geneblocks corresponding to the HC and LC variable regions of a tubulin scFv-C (AA345) (Lima 528 and Cosson, 2019) were designed. N-terminal signal peptide sequences were added to both the $\mathrm{HC}$ and 529 LC variable regions (Burton, 1994; Yu et al., 2006). PCR fragments corresponding to the rabbit lgG530 specific LC and $\mathrm{HC}$ constant regions were generated and, together with the $\mathrm{HC}$ and LC variable regions, 531 were cloned into the rMAbParent plasmid using the Gibson assembly method. Descriptions of all 532 plasmids generated in this study are listed in Table 1.

Cell culture. Human HEK293 suspension culture cells (Expi293F) were cultured in Expi293F expression media (Fisher Scientific) and maintained at $37^{\circ} \mathrm{C}$ in $8 \% \mathrm{CO}_{2}$ in $125 \mathrm{~mL}$ spinner flasks on an orbital shaker rotating at $125 \mathrm{rpm}$. HeLa cells were cultured in DMEM supplemented with 10\% FBS and 1\% antibiotic/antimycotic solution and maintained at $37^{\circ} \mathrm{C}$ in $5 \% \mathrm{CO}_{2}$.

Expi293F cell transfection. HEK293 Expi293F cells were grown to $30 \mathrm{~mL}$ volumes in $125 \mathrm{~mL}$ spinner flasks. For generation of full-length antibodies, cells were treated as follows: $24 \mathrm{hr}$ prior to transfection, cells were seeded at $0.9 \times 10^{6}$ cells $/ \mathrm{mL}\left(27 \times 10^{6}\right.$ cells total) with a viability no less than $90 \%$ (typically $94-99 \%$ viability). On the day of transfection, cells were counted and $30 \times 10^{6}$ cells (at $>90 \%$ viability) were pelleted by centrifugation at $2000 \times \mathrm{g}$ for $15 \mathrm{~min}$ at $4^{\circ} \mathrm{C}$. The resulting supernatant was aspirated off and the pellet was gently resuspended in $15 \mathrm{~mL}$ fresh Expi293F media. Spinner flasks were returned to the incubator while transfection reactions were prepared. For transfection, $100 \mu$ of polyethylenimine (PEI) (Polysciences Inc.) at $1 \mathrm{mg} / \mathrm{mL}$ was added to $1 \mathrm{~mL}$ Optimem media (Gibco). In a second tube, 50 $\mu \mathrm{g}$ LC plasmid and $35 \mu \mathrm{g} \mathrm{HC}$ plasmid were mixed with $1 \mathrm{~mL}$ Optimem media. The two separate tubes were incubated for $5 \mathrm{~min}$ at room temperature with occasional flicking. After $5 \mathrm{~min}$, the contents of the two tubes were combined and mixed by flicking every $3 \mathrm{~min}$ for a total of $20 \mathrm{~min}$ at room temperature. After $20 \mathrm{~min}$, the mixture was added to the $15 \mathrm{~mL}$ Expi293F culture and incubated overnight, rotating at $125 \mathrm{rpm}$. Approximately $15 \mathrm{hr}$ later, $15 \mathrm{~mL}$ fresh Expi293F media was added to the original $15 \mathrm{~mL}$ culture, as well as $300 \mu \mathrm{l}$ of $220 \mathrm{mM}$ valproic acid (Sigma). Cells were subsequently cultured for an additional 4 days, after which cells were pelleted by centrifugation at $2000 \mathrm{xg}$ for $15 \mathrm{~min}$ at $4^{\circ} \mathrm{C}$. The supernatant was harvested and filtered through a $0.2 \mu \mathrm{m}$ filter (GenClone). The volume of the filtered supernatant was measured, and 1.0 M Tris-HCL, $\mathrm{pH} 7.4$ was added to bring the $\mathrm{pH}$ to between 7.4-7.7. The filtered supernatant was stored at $4^{\circ} \mathrm{C}$ until purification, which was optimally within 1 day of harvesting. 
560 volume of $40 \mathrm{~mL} 1 \mathrm{X}$ TBS, $\mathrm{pH}$ 7.5. Three $\mathrm{mL}$ of the washed slurry was added to the $30 \mathrm{~mL}$ of filtered

561 Expi293F cell supernatant and gently inverted for $12 \mathrm{hr}$ at $4^{\circ} \mathrm{C}$. Following the $12 \mathrm{hr}$ incubation, the 562 antibody-containing cell supernatant plus Protein A Sepharose mixture was added to a $9 \mathrm{~cm} \mathrm{high,} 2 \mathrm{ml}$ 563 bed volume $(0.8 \times 4 \mathrm{~cm})$ empty polypropylene column (BioRad) fitted with a two-way stopcock up to the 564 fill line. A funnel reservoir was attached to the top of the column and the remaining cell 565 supernatant/Protein A slurry was poured into the funnel. The column and the reservoir were transferred 566 to a $4^{\circ} \mathrm{C}$ cooler, covered loosely, and left to settle for $1 \mathrm{hr}$. After $1 \mathrm{hr}$, the stopcock was opened and the 567 flow-through was collected at a flow rate of $1 \mathrm{~mL} / \mathrm{min}$. Once the cell supernatant approached the top of 568 compacted Protein A slurry (with $\sim 1 \mathrm{~mL}$ remaining), the column flow was stopped and the flow-through 569 was added back to the column/funnel for a second round of binding. The column was left to settle for 15 $570 \mathrm{~min}$, the stopcock was opened and the flow-through was again collected at $1 \mathrm{~mL} / \mathrm{min}$. After the flow571 through approached the compacted slurry, $3 \mathrm{~mL}$ of $1 \mathrm{X}$ TBS $(\mathrm{pH} 8.0)$ was added to the column and 572 incubated for $15 \mathrm{~min}$. After $15 \mathrm{~min}$, the flow-through was collected at $1 \mathrm{~mL} / \mathrm{min}$. To elute the purified 573 antibody, $9 \mathrm{~mL}$ of low $\mathrm{pH}$ elution buffer $(0.15 \mathrm{M} \mathrm{NaCl}, 0.1 \mathrm{M}$ glycine, $\mathrm{pH} 2.95)$ was added to the column, 574 which was then connected to a peristaltic pump (BioRad). The flow rate was adjusted to $5 \mathrm{~mL} / \mathrm{min}$, and 575 the eluate was collected in a $15 \mathrm{~mL}$ conical tube containing $0.9 \mathrm{~mL} 1 \mathrm{M} \mathrm{Tris}-\mathrm{HCl}, \mathrm{pH} 8.0$. The eluate was 576 then dialyzed and concentrated by transferring it to pre-soaked dialysis membrane (SpectrumLabs), 577 which was then placed into $1 \mathrm{~L}$ of $1 \mathrm{X}$ phosphate buffered saline (PBS) buffer $(137 \mathrm{mM} \mathrm{NaCl}, 2.7 \mathrm{mM}$ $578 \mathrm{KCl}, 4.3 \mathrm{mM} \mathrm{Na}_{2} \mathrm{HPO}_{4}, 1.47 \mathrm{mM} \mathrm{KH}_{2} \mathrm{PO}_{4}, \mathrm{pH} 7.4$ ) and gently stirred at $4^{\circ} \mathrm{C}$ for $4 \mathrm{hr}$. After $4 \mathrm{hr}$, the $1 \mathrm{X}$ 579 PBS was replaced and incubated overnight at $4^{\circ} \mathrm{C}$. Purified, dialyzed antibodies were retrieved from the 580 dialysis tubing and subsequently concentrated in a 10,000 kDa cutoff concentrator (Millipore) to final 581 volume of between 100-200 uL. The protein concentration was calculated, and glycerol was added to a 582 final concentration of $15 \%$. Purified, concentrated antibodies were stored in $2-10 \mu$ laliquots at $-20^{\circ} \mathrm{C}$.

584 Cell treatments. For live-cell imaging experiments, HeLa cells were seeded and imaged in 35-mm glass585 bottomed dishes (constructed in-house). For fixed-cell analysis, cells were grown on sterile, acid-washed 586 coverslips in six-well plates. siRNAs were transfected into HeLa cells using $6 \mu$ l Oligofectamine (Fisher 587 Scientific) and $160 \mathrm{nM}$ of the appropriate siRNA: siHec1 (5'-CCCUGGGUCGUGUCAGGAA-3'); siBubR1 588 (5'-AAGGAGACAACUAAACUGCAA-3'); siMad2 (5'-CUGAAAGUAACUCAUAAUCUA -3') (Qiagen). For 589 transfection of the scFv or scFvC plasmids, $2.5 \mu$ l of Lipofectamine 3000 (Fisher Scientific) and 0.5-1 $\mu \mathrm{g}$ 590 of DNA were used. All siRNA and DNA transfections were incubated for 24-30 hr before the cells were 591 either imaged, fixed for immunofluorescence or harvested for immunoblot analysis. For some 592 experiments, cells were incubated with $500 \mathrm{nM}$ nocodazole (Tocris) for $15 \mathrm{hr}$ prior to fixation for 593 immunofluorescence or harvesting for immunoblot analysis. To inhibit Mps1 kinase, cells were treated 594 with $10 \mu \mathrm{M}$ reversine (Adooq Biosciences) for $1 \mathrm{hr}$ prior to fixation for immunofluorescence or harvesting 595 for immunoblot analysis. For bead loading experiments, directly labeled Fab-Hec1 ${ }^{647}$ (see below) was 
596 bead loaded into HeLa cells $1 \mathrm{hr}$ prior to fixing (Cialek et al., 2021). Briefly, $10 \mu \mathrm{l}$ of Fab-Hec1 ${ }^{647}$ were 597 placed directly atop growing HeLa cells in a 35- $\mathrm{mm}$ glass-bottomed dish. Glass beads were then 598 sprinkled atop the cells and the dish was agitated by sharply striking against the countertop. Fresh cell 599 media was added to the dish, which was returned to the incubator for $1 \mathrm{hr}$ prior to fixation.

601 Immunofluorescence. Cells were rinsed in 37 $\mathrm{C}$ PHEM buffer (60 mM PIPES, 25 mM HEPES, 10 mM 602 EGTA, and $4 \mathrm{mM} \mathrm{MgSO}_{4}, \mathrm{pH}$ 7.0) and then lysed for 5 min in freshly prepared lysis buffer (PHEM buffer $603+0.5 \%$ Triton X-100). Cells were subsequently fixed for $20 \mathrm{~min}$ at room temperature in freshly prepared $6044 \%$ paraformaldehyde in PHEM buffer $\left(37^{\circ} \mathrm{C}\right)$. After fixation, cells were washed $5 \times 3$ min in PHEM-T 605 (PHEM buffer + 0.1\% Triton X-100) and then blocked in 10\% boiled donkey serum (BDS) in PHEM for 1 $606 \mathrm{hr}$ at room temperature. Primary antibodies diluted in 5\% BDS were added to coverslips and allowed to 607 incubate for $1 \mathrm{hr}$ at room temperature. The following primary antibody and antibody fragment 608 concentrations were used for immunofluorescence: rMAb-Hec $1^{\mathrm{ms}}$ at $1.5 \mu \mathrm{g} / \mathrm{mL}$, rMAb-Hec $1^{\mathrm{rb}}$ at 0.2 $609 \mu \mathrm{g} / \mathrm{mL}, \mathrm{rMAb}-\mathrm{Hec}^{\text {hu }}$ at $1 \mu \mathrm{g} / \mathrm{mL}, \mathrm{rMAb}-\mathrm{pMELT}{ }^{\mathrm{rb}}$ at $1.9 \mu \mathrm{g} / \mathrm{mL}, \mathrm{rMAb}-\mathrm{CENP}-\mathrm{C}^{\mathrm{ms}}$ at $0.66 \mu \mathrm{g} / \mathrm{mL}, \mathrm{rMAb}-$ 610 CENP-C ${ }^{\text {hu }}$ at $0.6 \mu \mathrm{g} / \mathrm{mL}$, rMAb-BubR1 ${ }^{\mathrm{ms}}$ at $2.1 \mu \mathrm{g} / \mathrm{mL}, \mathrm{rMAb}-B u b R 1^{\text {hu }}$ at $0.85 \mu \mathrm{g} / \mathrm{mL}, \mathrm{rMAb}-3 \mathrm{~F} 3 / 2^{\mathrm{ms}}$ at 0.84 $611 \mu \mathrm{g} / \mathrm{mL}, \mathrm{rMAb}-\mathrm{Mad} 2-\mathrm{C}^{\mathrm{ms}}$ at $1.6 \mu \mathrm{g} / \mathrm{mL}, \mathrm{rMAb}-\mathrm{Mad} 2-\mathrm{C}^{\text {hu }}$ at $1.12 \mu \mathrm{g} / \mathrm{mL}, \quad \mathrm{scFvC}-\mathrm{Hec} 1^{\mathrm{rb}}$ at $0.5 \mu \mathrm{g} / \mathrm{mL}$, 612 scFvC-Mad2-C ${ }^{\text {rb }}$ at $1.0 \mu \mathrm{g} / \mathrm{mL}$, rMAb-tubulin ${ }^{\mathrm{rb}}$ at $1.2 \mu \mathrm{g} / \mathrm{mL}$, and rMAb-HA ${ }^{\mathrm{rb}}$ at $1.2 \mu \mathrm{g} / \mathrm{mL}$. After primary 613 antibody incubation, cells were rinsed $5 \times 3 \mathrm{~min}$ in PHEM-T and then incubated for $45 \mathrm{~min}$ at room 614 temperature with secondary antibodies conjugated to either Alexa 647 or Cy3 (Jackson ImmunoResearch 615 Laboratories, Inc.) at $1.5 \mathrm{ug} / \mathrm{mL}$ diluted in 5\% BDS. Cells were rinsed $5 \times 3$ min in PHEM-T, incubated in 616 a solution of $2 \mathrm{ng} / \mathrm{ml}$ DAPI diluted in PHEM, rinsed $5 \times 3$ min, quick-rinsed in PHEM, and then mounted 617 onto glass slides in an antifade solution ( $90 \%$ glycerol $+0.5 \% N$-propyl gallate). Coverslips were sealed 618 with nail polish and stored at $4^{\circ} \mathrm{C}$.

620 Imaging. All fixed cell images were acquired on an Inverted Olympus microscope incorporated into a GE 621 Ultra imaging system (GE Healthcare) with SoftWoRx software (GE Healthcare) using a 60X 1.42 NA 622 differential interference contrast Plan Apochromat oil immersion lens (Olympus) with a final magnification 623 of $107.6 \mathrm{~nm} /$ pixel at the camera sensor (edge4.2, PCO Inc.). For live-cell imaging experiments, cells were 624 imaged in 35-mm glass-bottomed dishes (constructed in-house) and imaged in Leibovitz's L-15 media 625 (Invitrogen) supplemented with 10\% FBS, 7 mM HEPES, 4.5 g/liter glucose, pH 7.0. Images were 626 captured on a Nikon Ti-E microscope equipped with a Piezo Z-control (Physik Instrumente), stage top 627 incubation system (Okolab), and spinning disk confocal scanner unit (CSUX1; Yokogawa), using a 60X, 628 1.49NA objective and an iXon DU888 EM-CCD camera (Andor). Five z-planes at $0.75 \mu \mathrm{m}$ steps, were 629 acquired every 3 min for the duration of filming using the $488 \mathrm{~nm}$ laser. 
631 Fluorophore conjugations. For direct labeling of the Fab fragment, full length $\mathrm{rMAb}-\mathrm{Hec} 1^{\mathrm{ms}}$ was first 632 digested using a Pierce Fab Preperation Kit (Fisher Scientific) according to the manufacturer's 633 instructions. Purified Hec1 Fab was then directly conjugated with Alexa 647 (Invitrogen) according to the 634 following procedure: $0.065 \mathrm{mg}$ of Fab-Hec1 ${ }^{\mathrm{ms}}$ was incubated with $6 \mu \mathrm{l} 1 \mathrm{M} \mathrm{NaHCO}_{3}$ and $1 \mu \mathrm{l}$ Alexa 647 635 (final reaction volume $50 \mathrm{uL}$ ). The tube containing the reaction mix was wrapped in foil, rotated for $30 \mathrm{~min}$ at room temperature, and then diluted with an additional $140 \mu$ of 1 X PBS. This solution was then added

637 to the center of a Nap-5 gel filtration column and allowed to enter the column via gravity. $500 \mu$ of $1 \mathrm{X}$ 638 PBS was added to the column and the fastest-eluting fluorescent band containing the fluorescently639 conjugated protein was collected in a fresh tube. Hec1 Fab ${ }^{647}$ concentration and labeling ratio was 640 calculated.

642 STORM imaging. Cells were seeded and fixed as above in 35-mm glass-bottomed dishes. The Hec1 643 Fab used for STORM was directly labeled as described above, but in addition to Alexa 647, the Fab was 644 also conjugated with Alexa 405 by adding $3 \mu \mathrm{l}$ of the dye to the same reaction volume. The directly 645 labeled Hec1 $\mathrm{Fab}^{405 / 647}$ was used at 1:500 following the above immunofluorescence procedure. For 646 imaging, STORM imaging buffer was made immediately before use according to Nikon STORM protocol: $24 \mu \mathrm{l}$ glucose oxidase, $280 \mu \mathrm{l}$ 1M MEA $2480 \mu \mathrm{l}(50 \mathrm{mM}$ Tris- $\mathrm{HCl}+10 \mathrm{mM} \mathrm{NaCl}+10 \%$ glucose). $2 \mathrm{~mL}$ of the imaging buffer was added to the dish and the cells were imaged on a Nikon Ti-Eclipse microscope using a 1.49NA 100X Plan Apo TIRF lens equipped with an iXon3 DU897 EM-CCD (Andor). STORM images were acquired using $405 \mathrm{~nm}$ and $640 \mathrm{~nm}$ lasers on N-STORM software, version 3.30.

Immunoblotting. Samples were run on 12\% SDS-polyacrylamide gels and subsequently transferred to $0.2 \mu \mathrm{m}$ polyvinylidene difluoride membrane (PVDF) (Millipore). Membranes were washed with 1X TBS and incubated with a $5 \%$ solution of BSA for $1 \mathrm{hr}$ at room temperature. Primary antibodies were added to membranes in quick-seal bags, and incubated, rocking for $1 \mathrm{hr}$ at room temperature. The following primary antibody and antibody fragment concentrations were used for immunoblotting: rMAb-Hec $1^{\mathrm{ms}}$ at $1.5 \mu \mathrm{g} / \mathrm{mL}, \mathrm{rMAb}-B u b R 1^{\mathrm{ms}}$ at $2.1 \mu \mathrm{g} / \mathrm{mL}, \mathrm{rMAb}-\mathrm{pMELT}{ }^{\mathrm{rb}}$ at $1.9 \mu \mathrm{g} / \mathrm{mL}$ and rMAb-Tubulin ${ }^{\mathrm{rb}}$ at $1.2 \mu \mathrm{g} / \mathrm{mL}$. Membranes were washed with TBS-T (1 X TBS + 0.05\% Tween-20) and incubated with HRP-tagged secondary antibodies for $1 \mathrm{hr}$ at room temperature. Membranes were washed with TBS-T and scanned on a chemiluminescence imager IA600 (GE Healthcare). For the KNL1 pMELT immunoblots, a truncated version of KNL1 with a molecular mass of $\sim 100 \mathrm{kDa}$ and containing multiple MELT motifs was transiently expressed in HeLa cells $24 \mathrm{hr}$ prior to processing for SDS-PAGE and immunoblot analysis. 
bioRxiv preprint doi: https://doi.org/10.1101/2021.09.10.455288; this version posted September 11, 2021. The copyright holder for this preprint (which was not certified by peer review) is the author/funder, who has granted bioRxiv a license to display the preprint in perpetuity. It is made available under aCC-BY-NC 4.0 International license.

\begin{tabular}{|c|c|}
\hline Plasmid name & $\begin{array}{c}\text { Description } \\
\end{array}$ \\
\hline pDL001_Hec1-ms_IgG_HC & $\begin{array}{l}\text { Hec1 heavy chain variable and constant regions (mouse) + exogenous } \mathrm{N} \text {-term signal } \\
\text { peptide }\end{array}$ \\
\hline pDL002_Hec1-ms_IgG_LC & $\begin{array}{l}\text { Hec1 light chain variable and constant region (mouse) + exogenous } \mathrm{N} \text {-term signal } \\
\text { peptide }\end{array}$ \\
\hline pDL003_Hec1-rb_IgG_HC & $\begin{array}{l}\text { Hec1 heavy chain variable region + rabbit heavy chain constant regions + exogenous } \\
\mathrm{N} \text {-term signal peptide }\end{array}$ \\
\hline pDL004_Hec1-rb_IgG_LC & $\begin{array}{l}\text { Hec1 light chain variable region + rabbit light chain constant region + exogenous } \mathrm{N} \text { - } \\
\text { term signal peptide }\end{array}$ \\
\hline pDL005_Hec1-hu_IgG_HC & $\begin{array}{l}\text { Hec1 heavy chain variable region + human heavy chain constant regions (UniProt } \\
\text { P01857) + exogenous } \mathrm{N} \text {-term signal peptide }\end{array}$ \\
\hline pDL006_Hec1-hu_IgG_LC & $\begin{array}{l}\text { Hec1 light chain variable region + human light chain constant region (UniProt P01834) } \\
+ \text { exogenous } \mathrm{N} \text {-term signal peptide }\end{array}$ \\
\hline pDL007_pMELT-rb_IgG_HC & $\begin{array}{l}\text { KNL1 pMELT heavy chain variable and constant regions (rabbit) + exogenous } \mathrm{N} \text {-term } \\
\text { signal peptide }\end{array}$ \\
\hline pDL008_pMELT-rb_IgG_LC & $\begin{array}{l}\text { KNL1 pMELT light chain variable and constant region (rabbit) + exogenous N-term } \\
\text { signal peptide }\end{array}$ \\
\hline pDL009_CenpC-ms_IgG_HC & $\begin{array}{l}\text { CENP-C heavy chain variable region + mouse heavy chain constant regions (from } \\
\text { Hec1 sequence) + exogenous } \mathrm{N} \text {-term signal peptide }\end{array}$ \\
\hline pDL010_CenpC-ms_IgG_LC & $\begin{array}{l}\text { CENP-C light chain variable region + mouse light chain constant region (from Hec1 } \\
\text { sequence) + exogenous } \mathrm{N} \text {-term signal peptide }\end{array}$ \\
\hline pDL011_CenpC-hu_IgG_HC & $\begin{array}{l}\text { Cenp-C heavy chain variable region }+ \text { human heavy chain constant regions (UniProt } \\
\text { P01857) + exogenous } \mathrm{N} \text {-term signal peptide }\end{array}$ \\
\hline pDL012_CenpC-hu_IgG_LC & $\begin{array}{l}\text { Cenp-C light chain variable region + human light chain constant region (UniProt } \\
\text { P01834) + exogenous } \mathrm{N} \text {-term signal peptide }\end{array}$ \\
\hline pDL013_BubR1-ms_IgG_HC & $\begin{array}{l}\text { BubR1 heavy chain variable and constant regions (mouse); (contains endogenous } \mathrm{N} \text { - } \\
\text { term signal peptide) }\end{array}$ \\
\hline pDL014_BubR1-ms_IgG_LC & $\begin{array}{l}\text { BubR1 light chain variable and constant region (mouse); (contains endogenous } \mathrm{N} \text { - } \\
\text { term signal peptide) }\end{array}$ \\
\hline pDL015_BubR1-hu_IgG_HC & $\begin{array}{l}\text { BubR1 heavy chain variable region + human heavy chain constant regions (UniProt } \\
\text { P01857) (contains endogenous } \mathrm{N} \text {-term signal peptide) }\end{array}$ \\
\hline pDL016_BubR1-hu_IgG_LC & $\begin{array}{l}\text { BubR1 light chain variable region + human light chain constant region (UniProt } \\
\text { P01834) (contains endogenous } \mathrm{N} \text {-term signal peptide) }\end{array}$ \\
\hline pDL017_Mad2C-ms_IgG_HC & $\begin{array}{l}\text { Mad2-C heavy chain variable and constant regions (mouse) (contains endogenous } \mathrm{N} \text { - } \\
\text { term signal peptide) }\end{array}$ \\
\hline pDL018_Mad2C-ms_IgG_LC & $\begin{array}{l}\text { Mad2-C light chain variable and constant region (mouse) (contains endogenous } \mathrm{N} \text { - } \\
\text { term signal peptide) }\end{array}$ \\
\hline pDL019_Mad2C-hu_IgG_HC & $\begin{array}{l}\text { Mad2-C heavy chain variable region + human heavy chain constant regions (UniProt } \\
\text { P01857) (contains endogenous } \mathrm{N} \text {-term signal peptide) }\end{array}$ \\
\hline pDL020_Mad2C-hu_IgG_LC & $\begin{array}{l}\text { Mad2-C light chain variable region + human light chain constant region (UniProt } \\
\text { P01834) (contains endogenous } \mathrm{N} \text {-term signal peptide) }\end{array}$ \\
\hline pDL021_3F3/2-ms_IgG_HC & $\begin{array}{l}\text { 3F3/2 heavy chain variable and constant regions (mouse) (contains endogenous } \mathrm{N} \text { - } \\
\text { term signal peptide) }\end{array}$ \\
\hline pDL022_3F3/2-ms_IgG_LC & $\begin{array}{l}\text { 3F } 3 / 2 \text { light chain variable and constant region (mouse) (contains endogenous } \mathrm{N} \text {-term } \\
\text { signal peptide) }\end{array}$ \\
\hline pDL023_Tub-rb_IgG_HC & $\begin{array}{l}\alpha \text {-tubulin heavy chain variable region + rabbit heavy chain constant regions + } \\
\text { exogenous } \mathrm{N} \text {-term signal peptide }\end{array}$ \\
\hline pDL024_Tub-rb_IgG_LC & $\begin{array}{l}\alpha \text {-tubulin light chain variable region + rabbit light chain constant region + exogenous } \\
\mathrm{N} \text {-term signal peptide }\end{array}$ \\
\hline pDL025_HA-rb_IgG_HC_15F11 & $\begin{array}{l}\text { HA-tag heavy chain hypervariable regions grafted into framework 15F11 scaffold } \\
\text { (Zhao et al., 2019) + rabbit heavy chain constant regions + exogenous N-term signal } \\
\text { peptide }\end{array}$ \\
\hline pDL026_HA-rb_IgG_LC_15F11 & $\begin{array}{l}\text { HA-tag light chain hypervariable regions grafted into framework } 15 \mathrm{~F} 11 \text { scaffold (Zhao } \\
\text { et al.. 2019) + rabbit light chain constant regions + exogenous N-term signal peptide }\end{array}$ \\
\hline pDL027_scFvC_Hec1-rb & $\begin{array}{l}\text { Hec1 heavy and light chain variable regions connected by linker + rabbit heavy chain } \\
\text { constant regions } 2 \text { and } 3+\text { exogenous } N \text {-term signal peptide }\end{array}$ \\
\hline pDL028_scFvC_Mad2C-rb & $\begin{array}{l}\text { Mad2-C heavy and light chain variable regions connected by linker + rabbit heavy } \\
\text { chain constant regions } 2 \text { and } 3+\text { exogenous } N \text {-term signal peptide }\end{array}$ \\
\hline pDL029_scFv_pMELT_GFP_NoSP & $\begin{array}{l}\text { KNL1 pMELT heavy and light chain variable regions connected by linker + GFP (no } \\
\text { signal peptide included) }\end{array}$ \\
\hline pDL030_scFvC_Hec1-rb_NoSP & $\begin{array}{l}\text { Hec1 heavy and light chain variable regions connected by linker + rabbit heavy chain } \\
\text { constant regions } 2 \text { and } 3 \text { (no signal peptide included) }\end{array}$ \\
\hline pDL031_scFvC_Mad2C-rb_NoSP & $\begin{array}{l}\text { Mad2-C heavy and light chain variable regions connected by linker + rabbit heavy } \\
\text { chain constant regions } 2 \text { and } 3 \text { (no signal peptide included) }\end{array}$ \\
\hline
\end{tabular}




\section{Acknowledgements}

The authors thank members of the DeLuca lab and Dr. Steven Markus for helpful advice on the project. We also thank Drs. Martha Cyert and Marc Kirschner for providing the 3F3/2 hybridoma cell line to the Gorbsky lab. This work was supported by grants from the National Institutes of Health, National Institute of General Medical Sciences to JGD (R35GM130365), TJS (R35GM119728), NZ (K99GM141453), GJG (R35GM126980), and DV (R01GM135391); and a grant from the National Science Foundation to TJS (MCB-1845761). SMA, LS and the Cell Technology Shared Resource are supported by Cancer Center Support Grant (P30CA046934).

\section{Competing Interests}

The authors have no competing financial interests to declare.

\section{References}

Alfaleh, M.A., H.O. Alsaab, A.B. Mahmoud, A.A. Alkayyal, M.L. Jones, S.M. Mahler, and A.M. Hashem. 2020. Phage Display Derived Monoclonal Antibodies: From Bench to Bedside. Front Immunol. 11:1986.

Almagro, J.C., M. Pedraza-Escalona, H.I. Arrieta, and S.M. Pérez-Tapia. 2019. Phage Display Libraries for Antibody Therapeutic Discovery and Development. Antibodies (Basel). 8.

Baker, M. 2015. Reproducibility crisis: Blame it on the antibodies. Nature. 521:274-276.

Berland, L., L. Kim, O. Abousaway, A. Mines, S. Mishra, L. Clark, P. Hofman, and M. Rashidian. 2021. Nanobodies for Medical Imaging: About Ready for Prime Time? Biomolecules. 11.

Bordeaux, J., A. Welsh, S. Agarwal, E. Killiam, M. Baquero, J. Hanna, V. Anagnostou, and D. Rimm. 2010. Antibody validation. Biotechniques. 48:197-209.

Bradbury, A., and A. Plückthun. 2015. Reproducibility: Standardize antibodies used in research. Nature. 518:27-29.

Bradbury, A.R.M., N.D. Trinklein, H. Thie, I.C. Wilkinson, A.K. Tandon, S. Anderson, C.L. Bladen, B. Jones, S.F. Aldred, M. Bestagno, O. Burrone, J. Maynard, F. Ferrara, J.S. Trimmer, J. Görnemann, J. Glanville, P. Wolf, A. Frenzel, J. Wong, X.Y. Koh, H.Y. Eng, D. Lane, M.P. Lefranc, M. Clark, and S. Dübel. 2018. When monoclonal antibodies are not monospecific: Hybridomas frequently express additional functional variable regions. MAbs. 10:539-546.

Burton, D.R., J. Pyati, R. Koduri, S.J. Sharp, G.B. Thornton, P.W. Parren, L.S. Sawyer, R.M. Hendry, N. Dunlop, P.L. Nara, and et al. 1994. Efficient neutralization of primary isolates of HIV-1 by a recombinant human monoclonal antibody. Science. 266:1024-1027.

Campbell, M.S., and G.J. Gorbsky. 1995. Microinjection of mitotic cells with the 3F3/2 antiphosphoepitope antibody delays the onset of anaphase. J Cell Biol. 129:1195-1204.

Chan, G.K., S.A. Jablonski, V. Sudakin, J.C. Hittle, and T.J. Yen. 1999. Human BUBR1 is a mitotic checkpoint kinase that monitors CENP-E functions at kinetochores and binds the cyclosome/APC. J Cell Biol. 146:941-954. 
Cheloha, R.W., T.J. Harmand, C. Wijne, T.U. Schwartz, and H.L. Ploegh. 2020. Exploring cellular biochemistry with nanobodies. J Biol Chem. 295:15307-15327.

Chen, Y., D.J. Riley, P.L. Chen, and W.H. Lee. 1997. HEC, a novel nuclear protein rich in leucine heptad repeats specifically involved in mitosis. Mol Cell Biol. 17:6049-6056.

Cialek, C.A., G. Galindo, A.L. Koch, M.N. Saxton, and T.J. Stasevich. 2021. Bead Loading Proteins and Nucleic Acids into Adherent Human Cells. J Vis Exp.

Cosson, P., and O. Hartley. 2016. Recombinant Antibodies for Academia: A Practical Approach. Chimia (Aarau). 70:893-897.

De Antoni, A., C.G. Pearson, D. Cimini, J.C. Canman, V. Sala, L. Nezi, M. Mapelli, L. Sironi, M. Faretta, E.D. Salmon, and A. Musacchio. 2005. The Mad1/Mad2 complex as a template for Mad2 activation in the spindle assembly checkpoint. Curr Biol. 15:214-225.

DeLuca, J.G., W.E. Gall, C. Ciferri, D. Cimini, A. Musacchio, and E.D. Salmon. 2006. Kinetochore microtubule dynamics and attachment stability are regulated by Hec1. Cell. 127:969-982.

DeLuca, J.G., and A. Musacchio. 2012. Structural organization of the kinetochore-microtubule interface. Curr Opin Cell Biol. 24:48-56.

Garg, B.K., and R.H. Loring. 2017. Evaluating Commercially Available Antibodies for Rat a7 Nicotinic Acetylcholine Receptors. J Histochem Cytochem. 65:499-512.

Gavilondo, J.V., and J.W. Larrick. 2000. Antibody engineering at the millennium. Biotechniques. 29:128132, 134-126, 138 passim.

Gorbsky, G.J., and W.A. Ricketts. 1993. Differential expression of a phosphoepitope at the kinetochores of moving chromosomes. J Cell Biol. 122:1311-1321.

Gray, A., A.R.M. Bradbury, A. Knappik, A. Plückthun, C.A.K. Borrebaeck, and S. Dübel. 2020. Animalfree alternatives and the antibody iceberg. Nat Biotechnol. 38:1234-1239.

Gray, A.C., S.S. Sidhu, P.C. Chandrasekera, C.F.M. Hendriksen, and C.A.K. Borrebaeck. 2016. AnimalFriendly Affinity Reagents: Replacing the Needless in the Haystack. Trends Biotechnol. 34:960-969.

Hara, M., and T. Fukagawa. 2020. Dynamics of kinetochore structure and its regulations during mitotic progression. Cell Mol Life Sci. 77:2981-2995.

Hayashi-Takanaka, Y., K. Yamagata, T. Wakayama, T.J. Stasevich, T. Kainuma, T. Tsurimoto, M. Tachibana, Y. Shinkai, H. Kurumizaka, N. Nozaki, and H. Kimura. 2011. Tracking epigenetic histone modifications in single cells using Fab-based live endogenous modification labeling. Nucleic Acids Res. 39:6475-6488.

Hoffman, D.B., C.G. Pearson, T.J. Yen, B.J. Howell, and E.D. Salmon. 2001. Microtubule-dependent changes in assembly of microtubule motor proteins and mitotic spindle checkpoint proteins at PtK1 kinetochores. Mol Biol Cell. 12:1995-2009.

Johnson, G., and T.T. Wu. 2000. Kabat database and its applications: 30 years after the first variability plot. Nucleic Acids Res. 28:214-218. 
Johnson, R.S., S.A. Martin, K. Biemann, J.T. Stults, and J.T. Watson. 1987. Novel fragmentation process of peptides by collision-induced decomposition in a tandem mass spectrometer: differentiation of leucine and isoleucine. Anal Chem. 59:2621-2625.

Katzman, B.M., K.M. Ness, and A. Algeciras-Schimnich. 2017. Evaluation of the CLSI EP26-A protocol for detection of reagent lot-to-lot differences. Clin Biochem. 50:768-771.

Kimura, H., Y. Hayashi-Takanaka, T.J. Stasevich, and Y. Sato. 2015. Visualizing posttranslational and epigenetic modifications of endogenous proteins in vivo. Histochem Cell Biol. 144:101-109.

Kixmoeller, K., P.K. Allu, and B.E. Black. 2020. The centromere comes into focus: from CENP-A nucleosomes to kinetochore connections with the spindle. Open Biol. 10:200051.

Laustsen, A.H., V. Greiff, A. Karatt-Vellatt, S. Muyldermans, and T.P. Jenkins. 2021. Animal Immunization, in Vitro Display Technologies, and Machine Learning for Antibody Discovery. Trends Biotechnol.

Leenaars, P.P., M.A. Koedam, P.W. Wester, V. Baumans, E. Claassen, and C.F. Hendriksen. 1998. Assessment of side effects induced by injection of different adjuvant/antigen combinations in rabbits and mice. Lab Anim. 32:387-406.

Lima, W.C. and Cosson, P. 2019. The AA344 and AA345 antibodies detect human tubulin by immunofluorescence in HeLa cells. Antib. Rep. 2(4):e108.

Lima, W.C., E. Gasteiger, P. Marcatili, P. Duek, A. Bairoch, and P. Cosson. 2020. The ABCD database: a repository for chemically defined antibodies. Nucleic Acids Res. 48:D261-d264.

Lischetti, T., and J. Nilsson. 2015. Regulation of mitotic progression by the spindle assembly checkpoint. Mol Cell Oncol. 2:e970484.

London, N., S. Ceto, J.A. Ranish, and S. Biggins. 2012. Phosphoregulation of Spc105 by Mps1 and PP1 regulates Bub1 localization to kinetochores. Curr Biol. 22:900-906.

Lyon, K., and T.J. Stasevich. 2017. Imaging Translational and Post-Translational Gene Regulatory Dynamics in Living Cells with Antibody-Based Probes. Trends Genet. 33:322-335.

Mapelli, M., L. Massimiliano, S. Santaguida, and A. Musacchio. 2007. The Mad2 conformational dimer: structure and implications for the spindle assembly checkpoint. Cell. 131:730-743.

McNeil, P.L., and E. Warder. 1987. Glass beads load macromolecules into living cells. J Cell Sci. 88 (Pt 5):669-678.

Mikhaylova, M., B.M. Cloin, K. Finan, R. van den Berg, J. Teeuw, M.M. Kijanka, M. Sokolowski, E.A. Katrukha, M. Maidorn, F. Opazo, S. Moutel, M. Vantard, F. Perez, P.M. van Bergen en Henegouwen, C.C. Hoogenraad, H. Ewers, and L.C. Kapitein. 2015. Resolving bundled microtubules using anti-tubulin nanobodies. Nat Commun. 6:7933.

Morisaki, T., K. Lyon, K.F. DeLuca, J.G. DeLuca, B.P. English, Z. Zhang, L.D. Lavis, J.B. Grimm, S. Viswanathan, L.L. Looger, T. Lionnet, and T.J. Stasevich. 2016. Real-time quantification of single RNA translation dynamics in living cells. Science. 352:1425-1429. 
Musacchio, A., and A. Desai. 2017. A Molecular View of Kinetochore Assembly and Function. Biology (Basel). 6.

Navarro, A.P., and I.M. Cheeseman. 2021. Kinetochore assembly throughout the cell cycle. Semin Cell Dev Biol.

Nicklas, R.B., S.C. Ward, and G.J. Gorbsky. 1995. Kinetochore chemistry is sensitive to tension and may link mitotic forces to a cell cycle checkpoint. J Cell Biol. 130:929-939.

Nijenhuis, W., Vallardi, G., Teixeira, A., Kops, G.J., and A. T. Saurin. 2014. Negative feedback at kinetochores underlies a responsive spindle checkpoint signal. Nat Cell Biol. 16:1257-64.

Panikar, S.S., N. Banu, J. Haramati, S. Del Toro-Arreola, A. Riera Leal, and P. Salas. 2021. Nanobodies as efficient drug-carriers: Progress and trends in chemotherapy. J Control Release. 334:389-412.

Pozner-Moulis, S., M. Cregger, R.L. Camp, and D.L. Rimm. 2007. Antibody validation by quantitative analysis of protein expression using expression of Met in breast cancer as a model. Lab Invest. 87:251260.

Ries, J., C. Kaplan, E. Platonova, H. Eghlidi, and H. Ewers. 2012. A simple, versatile method for GFPbased super-resolution microscopy via nanobodies. Nat Methods. 9:582-584.

Sachs, D.H., A.N. Schechter, A. Eastlake, and C.B. Anfinsen. 1972. An immunologic approach to the conformational equilibria of polypeptides. Proc Natl Acad Sci U S A. 69:3790-3794.

Saeed, A.F., R. Wang, S. Ling, and S. Wang. 2017. Antibody Engineering for Pursuing a Healthier Future. Front Microbiol. 8:495.

Santaguida, S., A. Tighe, A.M. D'Alise, S.S. Taylor, and A. Musacchio. 2010. Dissecting the role of MPS1 in chromosome biorientation and the spindle checkpoint through the small molecule inhibitor reversine. $J$ Cell Biol. 190:73-87.

Sasada, R., Marumoto, R., and Igarashi, K. 1988. Secretion of human EGF and IgE in mammalian cells by recombinant DNA techniques; use of a IL-2 leader sequence. Cell Struct Funct. 13:129-41.

Sato, Y., M. Mukai, J. Ueda, M. Muraki, T.J. Stasevich, N. Horikoshi, T. Kujirai, H. Kita, T. Kimura, S. Hira, Y. Okada, Y. Hayashi-Takanaka, C. Obuse, H. Kurumizaka, A. Kawahara, K. Yamagata, N. Nozaki, and H. Kimura. 2013. Genetically encoded system to track histone modification in vivo. Sci Rep. 3:2436.

Sedgwick, G.G., M.S. Larsen, T. Lischetti, W. Streicher, R.R. Jersie-Christensen, J.V. Olsen, and J. Nilsson. 2016. Conformation-specific anti-Mad2 monoclonal antibodies for the dissection of checkpoint signaling. MAbs. 8:689-697.

Shepperd, L.A., J.C. Meadows, A.M. Sochaj, T.C. Lancaster, J. Zou, G.J. Buttrick, J. Rappsilber, K.G. Hardwick, and J.B. Millar. 2012. Phosphodependent recruitment of Bub1 and Bub3 to Spc7/KNL1 by Mph1 kinase maintains the spindle checkpoint. Curr Biol. 22:891-899.

Shim, H. 2017. Antibody Phage Display. Adv Exp Med Biol. 1053:21-34.

Shukra, A.M., N.V. Sridevi, C. Dev, and M. Kapil. 2014. Production of recombinant antibodies using bacteriophages. Eur J Microbiol Immunol (Bp). 4:91-98. 
816

817

818

Skoufias, D.A., P.R. Andreassen, F.B. Lacroix, L. Wilson, and R.L. Margolis. 2001. Mammalian mad2 and bub1/bubR1 recognize distinct spindle-attachment and kinetochore-tension checkpoints. Proc Natl Acad Sci U S A. 98:4492-4497.

Stasevich, T.J., Y. Hayashi-Takanaka, Y. Sato, K. Maehara, Y. Ohkawa, K. Sakata-Sogawa, M. Tokunaga, T. Nagase, N. Nozaki, J.G. McNally, and H. Kimura. 2014. Regulation of RNA polymerase II activation by histone acetylation in single living cells. Nature. 516:272-275.

Traenkle, B., and U. Rothbauer. 2017. Under the Microscope: Single-Domain Antibodies for Live-Cell Imaging and Super-Resolution Microscopy. Front Immunol. 8:1030.

Valldorf, B., S.C. Hinz, G. Russo, L. Pekar, L. Mohr, J. Klemm, A. Doerner, S. Krah, M. Hust, and S. Zielonka. 2021. Antibody display technologies: selecting the cream of the crop. Biol Chem.

Varma, D., and E.D. Salmon. 2012. The KMN protein network--chief conductors of the kinetochore orchestra. J Cell Sci. 125:5927-5936.

Vazquez-Lombardi, R., D. Nevoltris, A. Luthra, P. Schofield, C. Zimmermann, and D. Christ. 2018. Transient expression of human antibodies in mammalian cells. Nat Protoc. 13:99-117.

Vleugel, M., M. Omerzu, V. Groenewold, M.A. Hadders, S.M.A. Lens, and G. Kops. 2015. Sequential multisite phospho-regulation of KNL1-BUB3 interfaces at mitotic kinetochores. Mol Cell. 57:824-835.

Wang, C., B. Han, R. Zhou, and X. Zhuang. 2016. Real-Time Imaging of Translation on Single mRNA Transcripts in Live Cells. Cell. 165:990-1001.

Waters, J.C., R.H. Chen, A.W. Murray, and E.D. Salmon. 1998. Localization of Mad2 to kinetochores depends on microtubule attachment, not tension. J Cell Biol. 141:1181-1191.

Weller, M.G. 2016. Quality Issues of Research Antibodies. Anal Chem Insights. 11:21-27.

Wimbish, R.T., and J.G. DeLuca. 2020. Hec1/Ndc80 Tail Domain Function at the KinetochoreMicrotubule Interface. Front Cell Dev Biol. 8:43.

Xenaki, K.T., S. Oliveira, and P.M.P. van Bergen En Henegouwen. 2017. Antibody or Antibody Fragments: Implications for Molecular Imaging and Targeted Therapy of Solid Tumors. Front Immunol. 8:1287.

Yamagishi, Y., C.H. Yang, Y. Tanno, and Y. Watanabe. 2012. MPS1/Mph1 phosphorylates the kinetochore protein KNL1/Spc7 to recruit SAC components. Nat Cell Biol. 14:746-752.

Yan, X., T.A. Hoek, R.D. Vale, and M.E. Tanenbaum. 2016. Dynamics of Translation of Single mRNA Molecules In Vivo. Cell. 165:976-989.

Yu, X., D.H. Gilden, A.M. Ritchie, M.P. Burgoon, K.M. Keays, and G.P. Owens. 2006. Specificity of recombinant antibodies generated from multiple sclerosis cerebrospinal fluid probed with a random peptide library. J Neuroimmunol. 172:121-131.

Zhang, G., T. Lischetti, D.G. Hayward, and J. Nilsson. 2015. Distinct domains in Bub1 localize RZZ and BubR1 to kinetochores to regulate the checkpoint. Nat Commun. 6:7162. 
851 Zhao, N., K. Kamijo, P.D. Fox, H. Oda, T. Morisaki, Y. Sato, H. Kimura, and T.J. Stasevich. 2019. A 852 genetically encoded probe for imaging nascent and mature HA-tagged proteins in vivo. Nat Commun. 853 10:2947.

854 Zhokhov, S.S., S.V. Kovalyov, T.Y. Samgina, and A.T. Lebedev. 2017. An EThcD-Based Method for 855 Discrimination of Leucine and Isoleucine Residues in Tryptic Peptides. J Am Soc Mass Spectrom. 856 28:1600-1611. 
bioRxiv preprint doi: https://doi.org/10.1101/2021.09.10.455288; this version posted September 11, 2021. The copyright holder for this preprint (which was not certified by peer review) is the author/funder, who has granted bioRxiv a license to display the preprint in perpetuity. It is made available under aCC-BY-NC 4.0 International license.

A

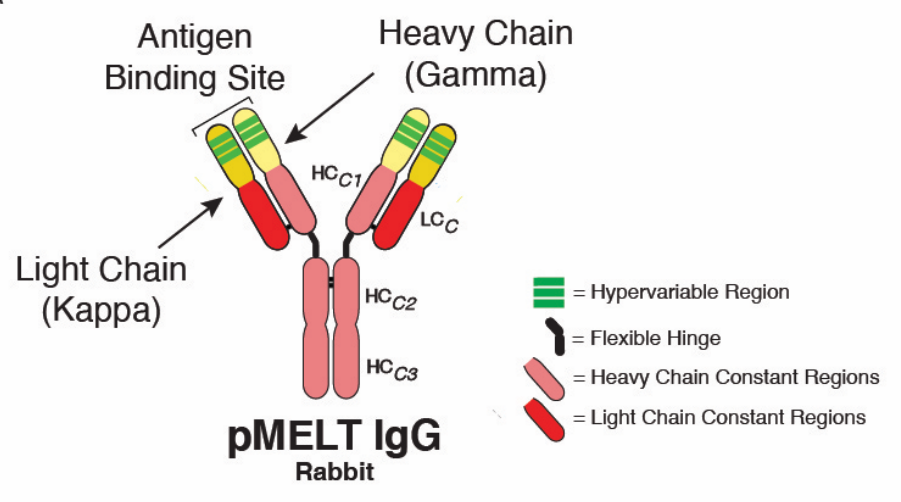

B

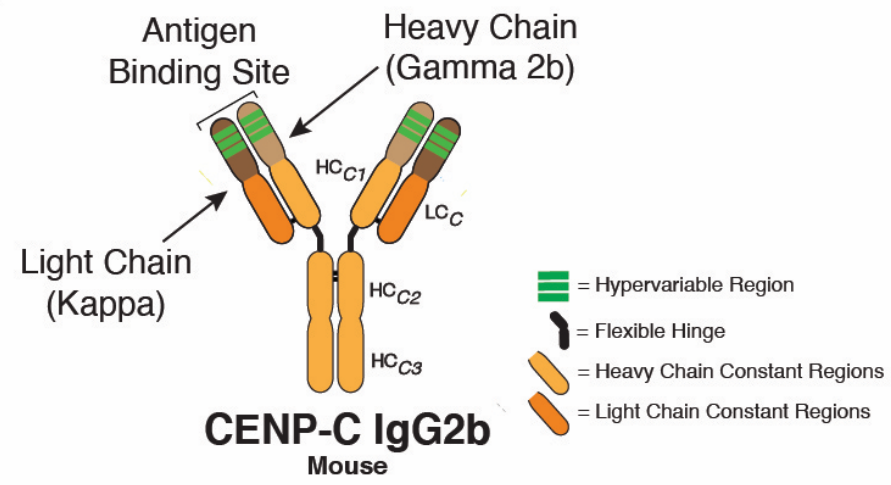

PMELT Antlbody Heavy Chain

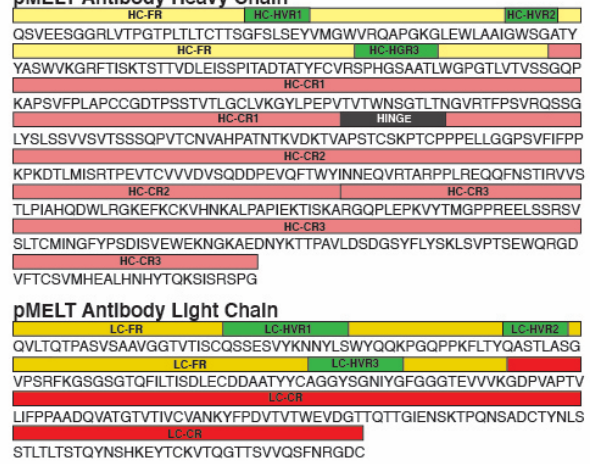

Cenp-C Antlbody Heavy Chaln

HC.FA
DVQLVESGGGLVPGGSRKLSCAASGFTFSSFGIMHWVRQAPEKGLEWVAYVSSGSN

HC.FP
TIYYADTVKGRFTISRDNPKNTLFLQMTSLRSEDTAMYYCAREKDYGMDYAMDYWGQ

HC.FR
GTSVTVSSAKTTAPPSVYPLAPGCGDTTGSSVTLGCLVKGYFPESVITVTWNSGSLSSS

VHTFPALLQSGLYTMSSSVTVPSSTWPSQTVTCSVAHPASSTTVDKKLEPSGPISTINPC

PPCKECHKCPAPNLEGGPSVFIFPPNC.CA2

HC.CR3
NNVEVHTAQTQTHREDYSNTIRVVSTLPIQHQDWMSGKEFKCKVNNKDLPSPIERTISK

IKGLVRAPQVYILPPAEQLSRKDVSLTCLLVGFNPGDSVEWTSNGHTEENYKDTAPVLD

SDGSYFIYSKLNMKTSKWEKTDSFSCNVRHEGLKNYYLKKTISASPGK

Cenp-C Antlbody LIght Chaln

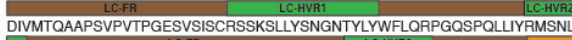
ASGVPDRFSGSGSGTGYTLRISRVEAEDVGVYYCMQHLEYPFTFGGGTKLEIKRADAA PTVSIFPPSSEQLTSGGASVVCFLNNFYPKDINVKWKIDGSERONGVLNSWTDQDSKD STYSMSSTLTLTKDEYERHNSYTCEATHKTSTSPIVKSFNRNEC

Supplemental Figure 1. KNL1 pMELT and CENP-C antibody classification and domain architecture. (A) Sequence data and domains for the KNL1 pMELT antibody are annotated for the heavy chain (HC) and light chain (LC) variable regions ( $\mathrm{HC}=$ =light yellow; $\mathrm{LC}=$ dark yellow), hypervariable regions (green), constant regions ( $\mathrm{HC}=$ light pink; $\mathrm{LC}=\mathrm{red}$ ), and the flexible hinge (dark gray). (B) Sequence data and domains for the CENP-C antibody are annotated for the heavy chain (HC) and light chain (LC) variable regions ( $\mathrm{HC}=$ light brown; $\mathrm{LC}=$ dark brown), hypervariable regions (green), constant regions ( $\mathrm{HC}=$ light orange; $\mathrm{LC}=$ dark orange), and the flexible hinge (dark gray). 
bioRxiv preprint doi: https://doi.org/10.1101/2021.09.10.455288; this version posted September 11, 2021. The copyright holder for this preprint (which was not certified by peer review) is the author/funder, who has granted bioRxiv a license to display the preprint in perpetuity. It is made available under aCC-BY-NC 4.0 International license.

A

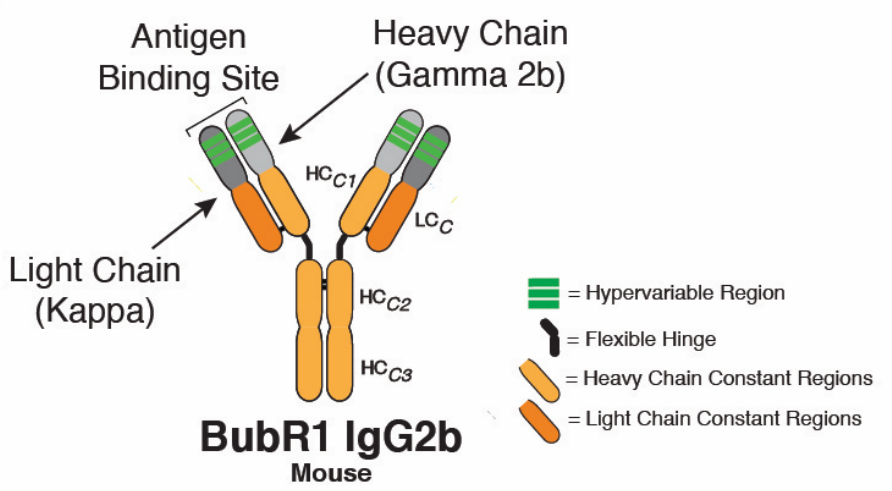

B

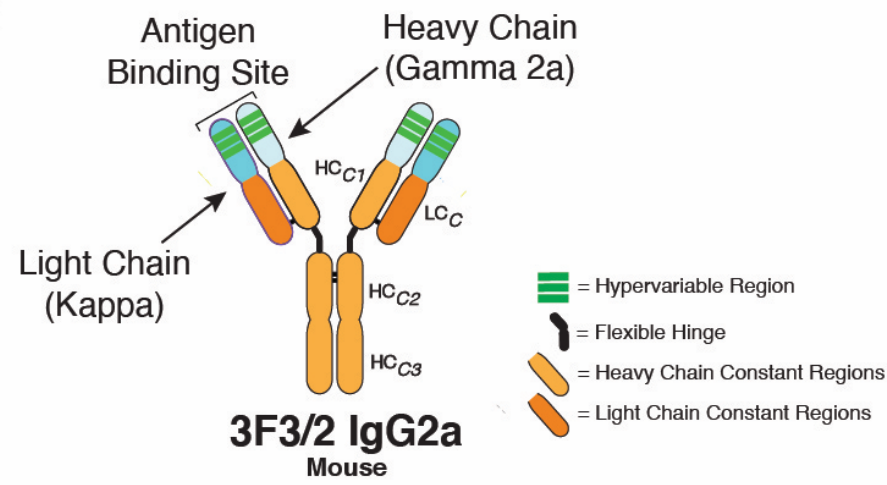

C

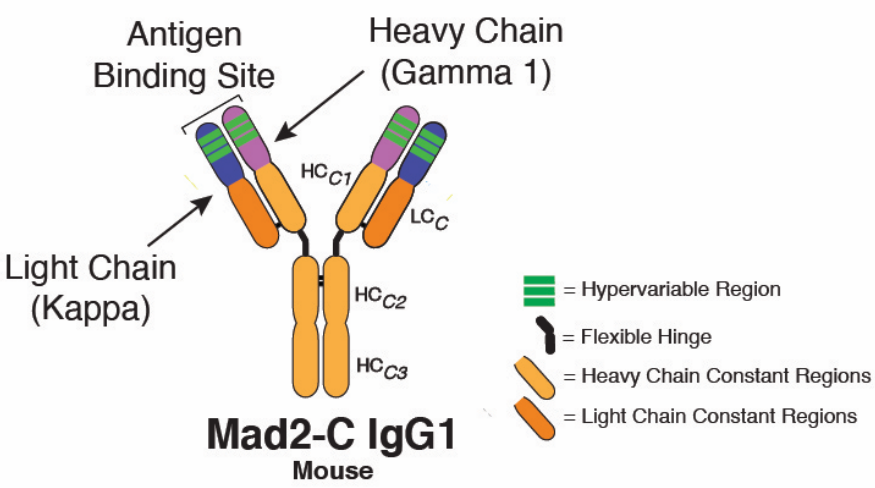

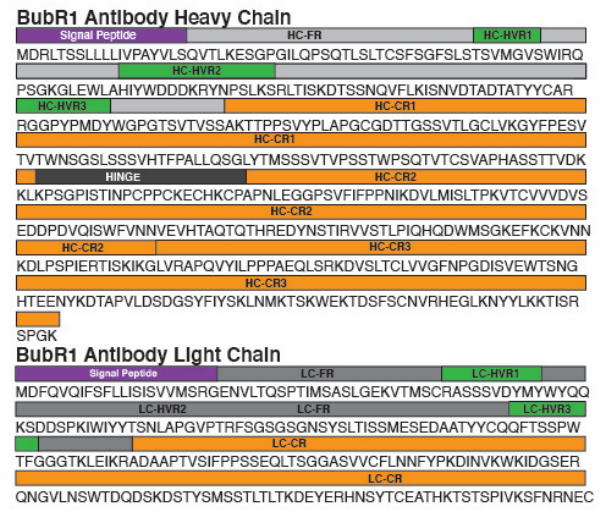

$3 F 3 / 2$ Heavy Chaln

MDSRLNLVFLVLILKGVQCDVQLVESGGGLVQPGGGSRKLSCAASGFTFSTFGMHWV QAPEKGLEWVAYISSGSSTIYYADTVKGRFTISRDNPKNTLFLOMTSLRSEDTAMYYCIR SGDSLFAYWGQGTLVTVSAAKTTAPSVYPLAPVCGDTTGSSVTLGCLVKGYFPEPVTLT WNSGSSSGVHTEPAVLOSDLYTLSSSVTVTSSTWPSOSITCNVAHPASSTKVDKKIEP,
HINGE RGPTIKPCPPCKCPAPNLLGGPSVFIFPPKIKDVLMISLSPIVTCVVVDVSEDDPDVQISW FVNNVEVHTAQTQTHREDYNSTLRVVSALPIQHQDWMSGKEFKCKVNNKDLPAPIERT HC.CA3
SKPKGSVRAPQVYVLPPPEEEMTKKOVTLTCMVTDFMPEDIYVEWTNNGKTELNYKNT EPVLDSDGSYFMYSKLRVEKKNWWVERNSYSCSVVHEGLHNHHTTKSFSPTPGK

3F3/2 Antlbody Light Chaln

MKLPVRLLVLMFWIPASSSDVVMTQTPLSLPVSLGDQASFSCRSSOSLVHSNGNTYLH WYLOKPGQSPKVLIYKVSNRFPGVPDRFSGSGSGTDFTLKISRVEAEDLGVYFCSQTT HVPYTFGGGTKLEIKRADAAPTVSIFPPSSEQLTSGGASVVCFLNNFYPKDINVKWKIDG SERONGVLNSWTDQDSKDSTYSMSSTLTLTKDEYERHNSYTCEATHKTSTSPIVKSFN RNEC

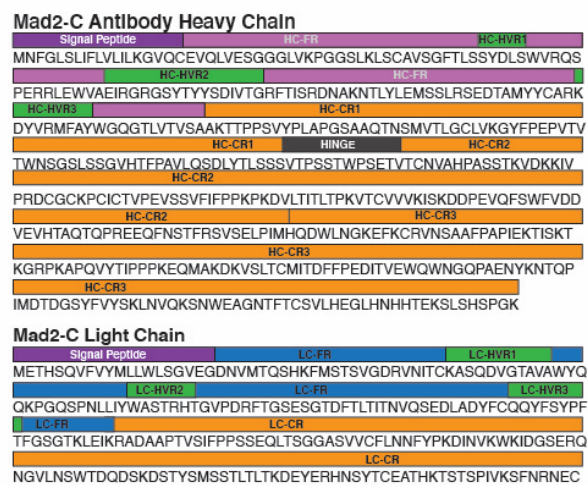

Supplemental Figure 2. BubR1, 3F3/2, and Mad2-C antibody classification and domain architecture. (A) Sequence data and domains for the BubR1 antibody are annotated for the heavy chain $(\mathrm{HC})$ and light chain $(\mathrm{LC})$ variable regions ( $\mathrm{HC}=$ light gray; $\mathrm{LC}=$ dark gray), hypervariable regions (green), constant regions ( $\mathrm{HC}=$ light orange; $\mathrm{LC}=$ dark orange), and the flexible hinge (dark gray). (B) Sequence data and domains for the 3F3/2 antibody are annotated for the heavy chain (HC) and light chain (LC) variable regions ( $\mathrm{HC}=$ light turquoise; $\mathrm{LC}=$ dark turquoise), hypervariable regions (green), constant regions ( $\mathrm{HC}=$ light orange; $\mathrm{LC}=$ dark orange), and the flexible hinge (dark gray). (C) Sequence data and domains for the Mad2-C antibody are annotated for the heavy chain $(\mathrm{HC})$ and light chain $(\mathrm{LC})$ variable regions ( $\mathrm{HC}=$ light purple; $\mathrm{LC}=$ dark purple), hypervariable regions (green), constant regions ( $\mathrm{HC}=$ light orange; $\mathrm{LC}=$ dark orange), and the flexible hinge (dark gray). 